\title{
Historical Geography in Japan since 1980
}

\author{
ONODA Kazuyuki \\ Kobe City Museum \\ MIYAMOTO Shinji \\ Okayama University of Science \\ FUJITA Hirotsugu \\ Kobe University \\ KOMEIE Taisaku \\ Kyoto University \\ KAWAHARA Norifumi \\ Ritsumeikan University \\ KAWAGUCHI Hiroshi \\ Tezukayama University
}

\begin{abstract}
This paper reviews major achievements of Japanese historical geography, history of cartography, and historical GIS since 1980. We can obtain fruitful research results in the three realms of historical geography - "real world", "imagined world", and "abstract world" - as defined by H. C. Prince. In "real world", reconstruction of landscapes and regional structure has been a basic subject. Modern historical geography established itself as a key platform to connect the past and the present world. There are two major new currents in this field: environmental history and interdisciplinary communication. Geographers, historians and archaeologists increasingly share resources and methodologies in historical geography to carry out interdisciplinary studies. As of 1980, some geographers started to study historical maps in "imagined world", in order to understand the cosmology of people in the past. Since the beginning of the 21st century, research works with historical GIS have well started in "abstract world", which will play a key role to integrate the results of individual research in the humanities and social sciences, including historical geography.
\end{abstract}

Key words: historical geography, landscape reconstruction, environmental history, history of cartography, historical GIS, interdisciplinary study

\section{Introduction}

This paper presents to Anglophone readers a compact review of the major progress in approximately three decades of Japanese historical geography. Historical geography has been one of the most active sub-disciplines of geography in Japan, partly due to copious historical resources including diversified documents, maps, small place names, and the landscape itself, 
and partly due to good interdisciplinary communication among the fields of geography, history, and archaeology. Current work by Japanese historical geographers can be seen in some associations and groups. The study group of historical geography in the Human Geographical Society of Japan held their $130^{\text {th }}$ meeting in November 2012. The Association of Historical Geographers in Japan published volume 54 of its journal, The Historical Geography, in 2012. A glossary (Fujioka et al. 1981) and a handbook (Arizono et al. 2001) of historical geography also reflect development in the field. Although more and more English papers including reviews (see K. Kobayashi and Kinda 1988; Kinda 1997) have been published and presentations (for example, see Kinda 2010) have been done by Japanese historical geographers, the major part of their research has focused on the historical geography of Japan and has been published only for Japanese readers. Hence, this paper reviews their progress since 1980, when the congress of the International Geographical Union was held at Tokyo.

While reconstruction of past geography or landscapes was the main stream of the field before the 1970s, we can observe new methodological challenges in the 1980s and the 1990s (Kinda 1997). The most active stream was the behavioural and perceptual approach, which was supported by a rich history of Japanese pictorial cartography and strongly influenced by the term "imagined world", one of three realms of historical geography that H. C. Prince (1971) suggests: "real", "imagined", and "abstract worlds". The research stream on the "imagined world" was prepared by Kikuchi's ambitious methodological integration of "real" and "imagined worlds" (T. Kikuchi 1977 \& 1987) and established by Research Group of the Illustrated Map of Katsuragawa (1988 \& 1989). Influenced by Cosgrove and Daniels (1988), Senda's creative works on spatial symbolism in ancient Japanese politics followed the methodological challenges (Senda 1991, 1992, 1996 \& 2004). It should be noted that a recent textbook of historical geography (Mizuuchi 2006) reflects the critical influences of social, cultural, and political geographies on the field that focus upon discourse, representation, and construction of space. Political, social, and cultural meanings of spatial imagery and representation have recently come to be the important point in modern historical geography (for example, Kato 2002; Mori 2005; Hamada 2006). A handbook in the field (Arizono et al. 2001) illustrates that the approaches to the "imagined world" are well established in Japanese historical geography as much as to the "real world". Although the "abstract world", which Prince (1971) suggests as the third realm, had few pages in the handbook, exploration of the "abstract world" progressed in the 1990s and 2000s due to the expeditious introduction of the historical geographical information system (HGIS). Using geographical documents and maps, especially administrative ones from early modern Japan, HGIS gives geographers a new power to analyze areal data geographically.

On the other hand, reconstruction of the past real geography continues to be a basic concern, partly because it should be the fundamental work of historical geography. T. Kikuchi (1984) provides a general description of the historical geography of Japan, while Kinda et al. (2010) provides a compact history of the Japanese landscape that reflects the abundant accumulation of studies by Japanese historical geographers. Three volumes of Asian Historical Geographies (Ishihara et al. 2007; Akiyama et al. 2008; Konagaya et al. 2007) show the expanded fields of Japanese historical geographers. Concerns about the past real geographies also evolve a trend in environmental history in the 1990s and 2000s. Reading the past geographies not from a humancentric view but in the context of a human-environment relationship led to many works on environmental history by historical geographers. Although the Oxford-Kobe Environmental Seminar in 2007 (Graduate School of Environmental Studies, Nagoya University 2008) showed increasing 
concern for environmental history among historical geographers, systematic publication of authentic textbooks on the environmental history of Japan remains the task of the future. This will be encouraged by the establishment of the Association for East Asian Environmental History (AEAEH), which held its first conference at the Academica Sinica of Taiwan in 2011, and will continue to convene biennially.

In this paper, two chapters are allocated for reviewing two characteristic trends in Japanese historical geography: cartographical issues (chapter V) and HGIS (chapter VI). The former has an important relation with progress in the behavioral and perceptual approach to the "imagined world". The latter explores the "abstract world" and represents the most active realm in recent Japanese historical geography (for example, Japan Council for Historical GIS Research 2012). Preceding these two chapters, we review general topics, including reconstruction of the past real geography and environmental concern from period to period according to the manner of Japanese history: (I) prehistoric and ancient era (before the twelfth century), (II) medieval era (from the twelfth century to the sixteenth century), (III) early modern era (from the seventeenth century to the nineteenth century), and (IV) modern era (after the nineteenth century).

\section{Prehistoric and Ancient Geography}

This brief part aims to offer a brief review of the prehistoric and ancient era in historical geography works authored by Japanese geographers. The review is based on books published from 1982 onwards. After briefly summarizing the recent trends in historical geography in Japan, the books are reviewed under the following headings: (1) Geo-environmental changes and human activities; (2) the restoration and reconstruction of ancient land development plans; and (3) interdisciplinary studies, environmental history, and environmental archaeology.

\section{(1) Geo-environmental changes and Human activities}

One recent research argument concerns the relationship between changes in the geomorphological environment and human adaptation; for example, paddy fields in the prehistoric period. From this viewpoint, there have been important geographical contributions relating to prehistoric and ancient environments and landforms. In addition, contributions from archaeologists, agriculturalists, and cultural anthropologists are valuable. In particular, finds from archaeological excavations since the 1980s have produced knowledge and new ideas and have contributed to a rapid increase in the quantity of data on prehistoric farming and cultural landscapes.

Many historical geographers have begun to pay more attention to the environment. Starting at the end of the 1970s, Kusaka (1980 \& 1991), Ono (1986), and N. Furuta (2005) reconstructed ancient landscapes and places for living, paying special attention to the physical environment, based on the archaeological and historical data. M. Takahashi (2003) discussed the geomorphologic environment and reclamation in the coastal plains after the end of the ancient period from the viewpoint of physical geography and geomorphology. Toyama (2006) compiles the vegetational changes and evolutionary processes of the alluvial plains of Japan and argues that there was a change in the relationship between short-term environmental changes and human activities. 


\section{(2) The restoration and reconstruction of ancient land development plans}

The main research on ancient cities involves the investigation of capital cities, which has been carried out not only by geographers but also by historians and archaeologists. The main focus of attention of historical geographers has been the restoration of city plans, the principle or origin of city planning (Hattori 1983; Seiichi Takahashi 1994; Ashikaga 1995), and study on the roots of ancient traffic (Y. Takahashi 1995). This is considered as part of the completion process of ancient land planning in Japan (Kinda 1985a), which was closely related to that of the jori plan.

The jori plan consists of the jori grid pattern, the unit measures of which are squares approximately 109 meters on a side. The jori indication system uses this as a basic unit (Nakano 1989). The jori plan was considered originally combined with the system of handen-shuju, which began in the latter half of the seventh century at the latest. While the first evidence shows that the jori indication system was written in 743 , it is thought that land allocation was carried out before this time, using small place names. This means that the jori plan was completed almost half a century after the establishment of ancient Japanese basic law that was derived from China. If this is true, it is highly probable that the jori plan was consolidated by adapting it to a unique Japanese context (Kinda 1985, 1993 \& 1998).

In the revised edition of their textbook, Fujioka et al. (1990) briefly summarize both the settlements in the jori system and the changes in rural landscapes from prehistoric to modern times.

\section{(3) Interdisciplinary studies, environmental history, and environmental archaeology}

Global environmental change is a hot topic within the geographer community as well as the larger scientific community. Physical geographers are involved in studies on global climate change, often tracing the impact of projected climate shifts on human activities such as agriculture. Human geographers are conducting studies on the human causes and consequences of global change. This is in part because by nature, area study is a research method grappling with complicated social problems that cannot be solved with separate disciplines.

Since the 1980s, prehistoric and ancient historical geography studies have developed rapidly as "interdisciplinary studies," combined with archaeological studies (excavation data) or historical studies (documents). Some research investigates the relationship between human activities and changes in the natural environment, such as sedimentary environments and climate. In particular, Yasuda (1980 \& 1990) treated the environmental problem by founding a field what he called "environmental archaeology". The main interest of most physical geographers has been natural environmental changes, such as the earth's system. However, environmental archaeology focuses on the relationship between nature and human activities as same as environmental history does. Other remarkable characteristics of prehistoric studies include nearly comprehensive or ephemeral studies with archaeology or history. Such studies will increase in the future, although comparative studies have traditionally been conducted in historical geography.

The next decade of historical geographical studies in Japan will be even more exciting and fruitful if continuous efforts are made in (1) discovering original materials; and (2) introducing methods from other ephemeral sciences. Historical geography has been greatly influenced by findings of historians and archaeologists. 


\section{Medieval Geography}

This chapter reviews the major developments in medieval historical geography. It first provides an overview of the most influential works in urban and rural geography, respectively, and then addresses specific themes within the two fields.

Medieval Japanese cities succeeded many elements of the ancient cities that had been influenced strongly by China. Kyoto, the 1,000-year-old capital of Heian-kyo, is a typical example, and many archaeological excavations have been conducted there. However, it is difficult to trace out a detailed historical geography of Kyoto from the archaeological remains because of the small size and fragmented nature of most of its ruins. On the other hand, kokufu, the ancient provincial capital cities, contained a number of government offices and residences around the core of the government bureau, or along the axis of an urban road, in a "discontinuous neighborhood-functional node pattern" (Kinda 1995). As kokufu features a dispersed and functional node spatial structure, some scholars argue that the kokufu and fuchu (the medieval provincial capital cities) had the same spatial pattern in the medieval period.

An orthodox analytical approach to historical geography of medieval cities that examines the land division patterns of modern cadastral surveys can be found in K. Kobayashi's works on castle towns in the Sengoku Period, a late medieval era marked by many wars. In his first study of the Ichijodani castle town in the Echizen Province, K. Kobayashi (1985) discovered what seemed to be a group of vassals' residences surrounding the Asakura clan's mansion. K. Kobayashi's hypothesis was confirmed by succeeding archaeological excavations. The spot was designated as a special historical site and has since been developed into a historical park. Additionally, K. Kobayashi (1985) published a volume of research on reconstructing settlements as regional centers on the Owari Plain, in the feudal domain of Mori, and throughout Tosa Province. Adapting this method to the Nambokucho Period - the era of the two emperors' feud in the middle medieval period - K. Kobayashi (1986) noticed that cadastral maps confirm a nearly reed-shaped land division pattern in Bitchu Province. And he attempted to recreate the landscape formed by the temporary dwellings of merchants in a market court.

Yamamura (2009) has carried on the tradition of examining land division patterns through the use of modern cadastral maps. Dividing the research period into smaller time divisions, she has created distribution maps for each time frame and consistently used comparative research methods. Beginning with research on Kamakura, the seat of the military government of the Kamakura shogunate, she analyzed the Otomo clan's castle town of Funai in the Sengoku Period, which had developed from the ancient capital of Bungo Province; Yamamura also analyzed the capital of Nagato Province. She argues that the picture maps from this era provide important evidence of the ideas held by the mapmakers and policy makers. Yamamura suggests that we need to pay attention to new methods for deciphering the content revealed by these documents.

Another important subject in medieval historical geography is Jinaimachi, or the settlements within Buddhist temple precincts. Mizuta (1978), Kanai (2004) and Amano (1996) are the principal proponents of this approach. In addition to these scholars, H. Fujita (2012) examines the urban systems and distributions of cities themselves that formed the background for the market court landscape in the medieval period, drawing a line at reconstruction research that uses cadastral survey maps. He points out the potential methodological problems of using 
cadastral maps from the modern period to investigate the landscapes of cities and towns in the medieval period.

Two scholars of history and architecture who have had an important influence on urban historical geography have to be mentioned here. First, the historian Amino (1976 \& 1978) suggested understanding markets and cities in medieval Japan as places of muen, or "nonrelationship," which were independent of political domination. These places, instilled with this principle of separation, were home to "non-agricultural people," or merchants who were not taxed by the local authorities and who had obtained special privileges to freely come and go between the various provinces. These sites can also be understood as "urban-like places." Second, examining the spatial characteristics of "temple precincts" and "towns," Takeshi Ito (2003) has contrasted the former, which developed as planet clusters organized in concentric circles around a central core, with the latter, which were organized in a linear cluster pattern along the axis of a road.

Next, we turn to research on rural historical geography. In contrast with the medieval cities mentioned above, the Chinese influence on rural medieval villages has not necessarily been the primary focus of historical geographers. Although a spatial control system using the jori grid plan appeared to have originated in China, scholars eventually came to believe that this plan is unique to Japan. On the other hand, the environmental history of medieval rural villages has become an important topic in historical geography, as shown in the work of Sano (2008). She has considered the use of the lakeshore environment and resource management around the province of Oumi, which is situated on the shores of Lake Biwa, Japan's largest lake. In regard to medieval development and the landscape of rural settlement, Yoshida (1983 \& 2009) and Toshikazu Ito (1998 \& 2000) have also examined medieval rural settlements, lending their attention to problems of management as well.

Picture maps of medieval shoen, or feudal manors, also provide resources for some noteworthy discussion. Although this will be reviewed in the following chapter on cartography, we will also refer to important books relating to the perspective of rural historical geography in this chapter. Dealing with shoen picture maps of Katsuragawa, in Oumi Province, the Research Group of the Illustrated Map of Katsuragawa (1982) hypothesized that the spatial perceptions of people living in Katsuragawa were expressed in the symbols and depictions found on maps, and attempted to understand these perceptions by referring to theories of semiotics. This was nothing more than a geographical understanding and a response to the fact that humanistic geography was being promoted in the field of human geography during this period. This monumental work influenced the field of historical research as well because this was a joint research project with historians. The reviewer of this chapter, who was a member of the research group, did not feel any kind of dependent relationship to history. Subsequently, the research group itself broadened its focus beyond the Katsuragawa map and thus advanced their discussion, the results of which have been brought together in two volumes put out by the Research Group of the Illustrated Map of Katsuragawa (1988 \& 1989).

The basis for this debate was the collection of shoen picture maps produced by Nishioka (1976 \& 1977). In addition, another manor map collection produced by the Historiographical Institute of the University of Tokyo (1988-2002) attempted to provide an exhaustive compilation of photographs, including photographs of items that had been discovered after the completion of the previous study. On the other hand, the volume edited by Koyama et al. (1997) limited itself to the most noteworthy items from this collection and added explanations and interpretations 
in a uniform style.

One example of truly interdisciplinary collaborative research was a picture map analysis and reconstruction of the landscape from ancient times through the medieval period that focused on the Nukata-dera Garan narabi ni Jori-zu, a national treasure picture map that belongs to the National Museum of Japanese History (Nito 2001). The area surrounding Nukata-dera Temple (now in Yamato Koriyama City, in Nara Prefecture) is one of the few locations where the historical landscape remains intact today. H. Fujita (2009) has also examined the land on picture maps that formerly belonged to Saidaiji Temple in Yamato Province. Aoyama (2007) also pushed forward research on the Hineno Village picture map from Izumi Province. Yoshida (2008) has focused on the medieval Honedera Village picture maps, and while comparing and contrasting these with the contemporary rural landscape, has stressed the importance of preserving traditional rural landscapes.

Finally, the direction of recent historical geographic research on the medieval period can be summarized with two major points. The first is that collaboration with related academic disciplines such as history and archaeology is increasingly more common. The second is related to the first and concerns the frequent analysis of cadastral survey maps. This methodological approach had been unique to historical geography but is now being developed in history and archaeology as well, particularly for the study of the medieval period. It can certainly no longer be said to belong exclusively to historical geography. This reviewer believes that the historicogeographical character of cadastral survey maps, which were produced throughout the country at the beginning of the modern period, can be best understood through the lens of the history of cartography from the early modern period. However, this question will probably require further debate.

\section{Early Modern Geography}

Kinsei, or the early modern era in the history of Japan, is generally understood to have been from the late years of the sixteenth century to the Meiji Restoration of 1867: namely, the three centuries of military governance by the Tokugawa shogunate and its predecessors. Development and achievement in economy and culture under the integrated powerful government have attracted many historical geographers. A textbook of historical geography of early modern Japan (Yamazaki 1985) illustrates the accumulation of studies on and the establishment of the field in the 1970s.

In the 1970s and 1980s, urban spatial structure (Ashikaga 1984; Fujioka 1983; K. Kobayashi 1985; Yamori 1987 \& Yamori 1988) and land reclamation (Fukuda 1986; T. Kikuchi 1986; Kitamura 1981; Miura 1983) were two major themes in the field, both of which shared the purpose of analyzing power relations embedded in newly designed spaces in early modern Japan. The studies on the former topic analyzed the plans of castle towns, which included physical structures for defense, regionalization according to the classes, and location of main streets, while researches on the latter focused on how the political and economical backgrounds reflected the morphology of the rural landscape.

However, the two topics have not necessarily developed after the leading scholars established their frameworks in the 1980s. Although the approach to social urban history by K. Kikuchi (1987) was an important attempt to understand early modern urbanism comprehensively, there were few books on the early modern city by historical geographers in the 1990s and 2000s. 
Seeking new approaches to the historical geographies of castle towns, Watanabe (2008) presents a detailed analysis of spatial control and the arrangement of samurai houses, and advocates the rereading of old town maps.

On the other hand, works on rural historical geographies have expanded into at least three topics. First, the spatial aspect of villages has been a basic question of Japanese rural society because mura, or a village, was a spatial unit officially demarcated in the late sixteenth century. Although there were few distinguished studies in the 1990s and 2000s after a pioneering work of Yamazumi (1982), recently Tatsuya Tanaka (2011) analyzed the making of early modern villages and Brown (2011) illustrated the joint ownership of arable land within a village. The unitary characteristics of villages provides a useful approach to regional, statistical, or integrated analysis of a certain area consisting of many villages, as shown in Kajikawa (1997) and Mizoguchi (2002). It is noteworthy to refer to Kinda (1985b \& 2001), which traces the evolution of the concept and landscape of grid patterns in the British colonies.

Secondly, agronomical change or adaption to the environment has also been an important question. A series of Arizono's studies of early modern agronomical literatures (Arizono 1986, 1997, 2005, 2007a \& 2007b) illustrate that local agriculture and food was an offspring of indigenous peasants' adaptation to the local environment and economy, while Iwasaki (1999) argues the making of commercial cotton region. Adaptation to the hydrological environment is a key focus to understanding rural Japan's reliance upon the rice paddy field, as shown by Kitamura (1990) and Hashimoto (2010). Moreover, a historical ecology of rice paddy lowlands (Noma 2009) and a comprehensive understanding of agricultural change in the Ryukyu Archipelago (S. Kobayashi 2003) illustrate an excellent fusion of historical geography and environmental history.

Thirdly, geographers who study subsistent economies without rice, which were historically regarded to be marginal in Japan, have constructed a unique field. Following Chiba's study on hunting and gathering in mountain villages (Chiba 1980 \& 1986), Mizoguchi (2002) and Komeie (2002) proposed a historical geography of mountain villages and multiplex subsistent economies. Other studies on forestry (Y. Fujita 1992, 1995 \& 1998), fishing (Hashimura 2009), lakefronts (Sano 2008), and mining (Harada 2011) also illustrate the diversity and development of early modern economies. These studies also lead us to a nuanced understanding of humanized nature, or the secondary nature (Sano 2008), that has been historically made and kept in the relationship between the environment and people. Environmental concern was also exerted in the studies of disaster (K. Kikuchi 1980 \& 1987) and flood (Y. Ito 1994 \& 2010).

Contrasting with the urban and rural studies mentioned above, other topics have not necessarily attracted many scholars, but still provide key viewpoints. With regard to communication, transportation, and distribution, studies on official highway systems (Tsuchida 1994 \& 2001) and fishmeal (E. Furuta 1996) suggest the importance of a spatial network within Japan. As Wigen (1995) showed the dynamic impact of transportation on peripheral regions, there are still several research topics on this theme that geographers have to work on. Religious beliefs also influenced the making of regionalization. As shown by Nagano (1987), Iwahana (1992 \& 2003), Tomohiko Tanaka (2004), and K. Miki (2010), Shintoism and Buddhism had measurable power in spatial organizations. Studies on population and its redistribution, which is the bottommost factor influencing human geographies, were not necessarily popular among historical geographers. However, a study of the Ainu people's move (Endo 1997) and other studies (Kawaguchi 1996 \& 2009a) have shared research concerns with historical demography. 


\section{Modern Geography}

Japanese geographers have attempted to grasp the Japanese modern era from the perspective of historical geography, a trend that has grown rapidly in popularity since the 1980s. Until as recently as 1980, Japanese geographers seemed to disregard the historical geographic study that surveyed the Meiji period (1868-1912). As Yamane (2012) points out, "the modern era" meant "the present" for these researchers. Researchers who were born after World War II took over the learned societies of the past and began to treat the modern era as history after the 1980s.

The historical geography of the modern era in Japan was compiled in The Historical Geography Review, which was initially edited by the Association of Historical Geographers in Japan. In the annual reviews (gakkai-tenbo), which introduced the geography review every year in the Japanese Journal of Human Geography (Jimbun Chiri), it was noted that the historical geography of modern Japan was a new development in the field of historical geography after 1990 (Kawaguchi 1990). The Association of Historical Geographers in Japan published a series for their $40^{\text {th }}$ and $50^{\text {th }}$ anniversaries in 1998 and 2008, introducing geographical trends from essays in The Historical Geography (Rekishi Chirigaku). Formerly, Aoki (1998) pointed out that there was more of a trend toward research concerning modern historical geography than early modern one, and this tendency increased after 1985.

Again in 2012, the historical geography of the modern era was featured in a special issue of The Historical Geography. This issue contains the comments of researchers from related academic fields and research findings from geographers from the 2011 Symposium of The Association of Historical Geographers in Japan, and discussed the subjects and trends of research in historical geography of the modern era (The Association of Historical Geographers in Japan 2012). Looking at the research in the symposium, there are examples of urban systems (Y. Abe 2012), "genealogical place theory," social history (Oshiro 2012), historical documents (Sekido 2012), collaborative research on economic history (Washizaki 2012), and foreign research methods and theories (Komeie 2012). These areas represent the main areas of focus in historical geography after the 1980s. According to Kono (2012), research on the modern era is gradually increasing. He also states that detailed research concerning regional subjects on landscape construction and clear regional characteristics has continuously advanced since the 1980s.

An important point in the modern era is that Japanese people migrated to various countries around the world. Historical geographers are researching what mechanisms were introduced in the Meiji period that gave rise to what is now modern Japan. In particular, historical geographers are investigating how modern Japan evolved as a country through the movement and will of pivotal individuals and groups (Yamane and Nakanishi 2007). This has been achieved through the establishment of the National Diet Library's Digital Library Website, where new documents on the modern era were discovered, including fire insurance maps (Ushizaki 2005) and directories (Otobe 2005). This has become a vital historical archive for historical geographers.

It is important to note that with the advancement of historical geography research of the modern era, many findings related to the once Japanese colonies of Korea, Taiwan, and the Sakhalin Island Group have been reported. For example, Yamamoto (2000, 2001 \& 2003) researched landscape reconstruction in Korea under Japanese colonization by using cadastral maps; Tawa (2006) used fishing industry documents to conduct research on Taiwan during the Japanese colonization period; Abe (2001) and M. Miki (2003) depicted the different areas 
occupied by Chinese, Korean, and Japanese people living in the Sakhalins. In addition, S. Kobayashi (2006) focused his study on colonial period maps (gaihozu) produced by the Japanese military. Historical geographers further focused on Japanese emigration to countries outside of the Japanese colonization area. For example, Ishikawa (1997) focused his research on overall emigration from Japan, Iida (2003) researched Japanese agricultural emigrants to Hawaii, while Yagasaki (1993) and Sugiura (2011) focused on Japanese emigrants to California, and Hiraoka (2003) focused on Japanese emigrants to the islands of the Pacific.

Many pre-1980 historical geographers paid little attention to Japanese emigration movements and primarily focused on studies relating to Japanese, Asian, and Western history. Part of the reason for this was the difficulty involved on many levels with researching Japanese colonies during the post WWII period. However, 60 years later, Japanese emigration research is now being reexamined. Japanese migration movements as viewed from within the discipline of historical geography have had a large effect on researchers from related fields in recent years (Yoneyama and Kawahara 2007).

\section{History of Cartography: Since the Paradigm Shift}

Since the 1980s, research on the history of cartography in Japan has been greatly influenced by the paradigm shift in map history research in Britain and America. Partially based on the traditional approach to map history, it is possible to point out following three approaches: (1) a semiotic approach that deciphers the cosmology in old maps; (2) the treatment of maps (and illustrated maps) as core source materials within the context of political history; and (3) sharing map materials through interdisciplinary research and consideration, an approach not limited purely to researchers of map history proper, with the construction of source material theories.

Among the experiments undertaken using the first approach, it would be well to mention the work of the Research Group of the Illustrated Map of Katsuragawa. Following the explication of this medieval picture map of Katsuragawa, a Buddhist estate in Oumi Province (Research Group of the Illustrated Map of Katsuragawa 1982), the Research Group's analysis of many different illustrated maps were brought together in the two-volume Cosmology of Illustrated Maps (1988 \& 1989). The semiotic approach and methodology that was set out by the Research Group were carried forward by Onodera (1991) and Aoyama (2007). Onodera interpreted both the contents depicted and the spatial perception of the mapmakers of illustrated maps of river transport during early modern era. Aoyama discussed the image of the world in early modern Japanese maps, of which origins date back to Gyoki-zu or an ancient map of Japan, as well as the depiction of space in illustrated maps of shoen, or medieval manors.

The second approach, which involved reading early modern administrative maps in their political context and focusing on the map makers and their techniques, was pioneered by Yamori in the 1970s (1973, 1978, 1979a, 1979b, 1982 \& 1989). Following Yamori, four works should be cited here for their noteworthy results. In the first of these, Fukai (1990) tracked down an original image of the mysterious cartographer Ochikochi Doin and, by deciphering a variety of sources, revealed that Doin was Hujii Hanchi, a medical practitioner in the feudal domain of Toyama and also known as a kemari-shi, a player of a traditional football-like game; Fukai was also able to describe Doin's career. Next, Kawamura (1992) examined the techniques by which the jikata illustrated maps on rural land ownership were created as administrative source materials in the early modern feudal system, and to what extent infrastructure improvements 
were carried out in village control, using the Hagi Domain as a case study. Narumi (2007), by contrast, looked at the surveying techniques used in the jikata illustrated maps - using the early modern villages of the Kinai provinces as his study area - examined the actual status and spread of the maps and focused on map production conducted through the surveying method known as mawari-kenchi or patrol inspection for demarcation. Most recently, arguing from a perspective that incorporates the knowledge network among map producers and focusing on the axis of a scholar of the Japanese chassics, Motoori Norinaga, and the cartographer Mori Koan, Uesugi (2010) has provided an examination from the perspective of the geographical thought of individuals, which has opened up a new research avenue that is highly interesting.

This approach can also be seen in a number of efforts at analysing Kuni-ezu, or provincial illustrated maps made by the Tokugawa shogunate, which became base maps of the national land area of Japan. Concerning Kuni-ezu, Kawamura (1984) has vigorously pursued research on their systematic production and the circumstances of their creation, as well as separate research on the maps in each province. Based on Kawamura's findings, the Research Group of the Kuni$e z u$ brought together information on the characteristics of Kuni-ezu that had survived from various parts of the country and the circumstances of their production (Research Group of the Kuniezu 2005). A survey was undertaken, chiefly by members of this same group, of the Kuni-ezu that P. F. B. von Siebold had taken back to Leiden in the Netherlands, and which are now in the possession of the Leiden University Library. In addition, Kuroda et al. (2001) compiled an ambitious collection of nine articles focusing on the conception and planning of illustrated maps and other maps, as well as their political and cultural history.

With regard to mapping history and the exploration of the northern part of the Japanese archipelago and the area around Sakhalin, which Western countries engaged in from the sixteenth century and the Tokugawa shogunate poured attention from the eighteenth century, one can cite the works of two authors: Akizuki (1999) and Takagi (2011). Akizuki painstakingly traced the development of mapping of the northern area in great detail by both East and West, and Takagi has presented the results of long years of hunting for maps of the northern area. Both authors have published reproductions of many map illustrations, and the contents of their work will indispensable to future research on the northern area. Meanwhile, since the beginning of recorded history, Japan has received more than a little influence from Chinese geography. Among examples, one can cite the Chinese-language world map Konyo bankoku zenzu as a representative map. Funakoshi (1986) has elucidated the factual verification and acceptance of the K'ang-hsi maps (the general name for the Koyo-zenranzu series of maps that were made by the order of the Chinese Emperor of K'ang-hsi), which were a stepping stone to knowledge of Japan's northern regions for Takahashi Kageyasu and other astronomers. In the same work, Funakoshi touches upon the results of explorations of the northern region and the world map of Arrowsmith, which had a great influence on the production of the Shintei bankoku zenzu, the highest-quality map in the world at the time.

As for the third approach, using interdisciplinary research, in Heiankyo-Kyoto: City Plans and Urban Structure, Kinda (2007) analyzes illustrated maps of Kyoto, which are rich in both quality and quantity, and focuses on city maps and the urban structure from ancient times to the near present. The book is a compilation of eleven different articles and features a narrative approach to urban history. The work of Fujii et al. (2007) on illustrated maps can also be highlighted; researchers in Japanese history, East Asian history and geography came together and conducted research that cut across the disciplines. Their volume collects 22 articles that 
interpret the worldview of the times from maps and illustrated map materials, both Eastern and Western, and they leave one with the feeling that the analysis of maps and illustrated map materials is not limited to the field of geography. Also worth mentioning are works by two researchers involved in this same project: Ouji (2007), who focuses on the background of the production of the Cantino Map from the Age of Discovery; and Miya (2007), who examines the worldview depicted in the Kon'itsukyori-rekidai-kokuto-no-zu (an early Joseon Dynasty 'map of historical capitals').

The Association of Historical Geographers in Japan has held conferences a number of times that have taken maps and illustrated maps as a joint topic, and in 2009 , it held a symposium on the theme of 'Reevaluating Old Maps as Tools for the Study of Historical Geography'(The Association of Historical Geographers in Japan 2010). According to Hasegawa and Onoda (2010, 2), the symposium was 'expected to be an occasion for rediscovering the meaning of old maps in historical geography and at the same time to open up new horizons in methodology and thought that utilise them'. In addition, the Historical Science Society of Japan has put together two special issues on the theme of 'Pictorial Maps in Early Modern Japan: A Comparative Perspective' with the intention of 'exploring the features of the old illustrated maps that were produced in Japan's early modern society, and to take up their history and the characteristics of their spatial perception in open debate' (Committee 2008, 1). Five of the seven articles published in Issue No. 841 discuss the analysis of illustrated maps, either scientific analysis of the pigment materials used in the maps' production, analysis of the master model map makers, or analysis of the surface technology (Historical Science Society of Japan 2008). According to Suigmoto et al. (2011), plans are afoot to explore the materials science of old maps, although limited to maps of the early modern period.

Other works worthy of special mention are the three volumes that bring together the research findings of Unno (2003, 2004 \& 2005). Additionally, posthumous volume (Unno 2010) examines the establishment of the atlas (Kuang-Yu-t'u) and its relationship with variant books under the Chinese Ming Dynasty, which discussed influence to the inside and outside the country. The last of these can be said to be required reading for anyone studying the history of mapping in Japan or East Asia.

In addition, the digital archiving of old maps and illustrated maps held by various institutions in Japan is proceeding, and it is becoming possible to make this a reality through websites. These are high-resolution images, and it will be possible for them to become resources for future research.

\section{Historical GIS}

Geographical Information System (GIS) has made remarkable progress since the 1980s. It is now developing interdisciplinary studies and this trend implies terra incognita in the so-called Geographical Information Sciences (GISc). During the 20th century many Japanese historical geographers doubted that GIS would enable them to make important discoveries, but a few of them tried to analyze historical materials under serious constraints using conventional types of GIS software that did not take into account temporal axis.

It is possible to combine historical materials such as handwritten documents, old maps, fieldwork results, statistics, archaeological artifacts, etc. with spatio-temporal information. However, it is very difficult to pinpoint the latitude, longitude and time of a given historical 


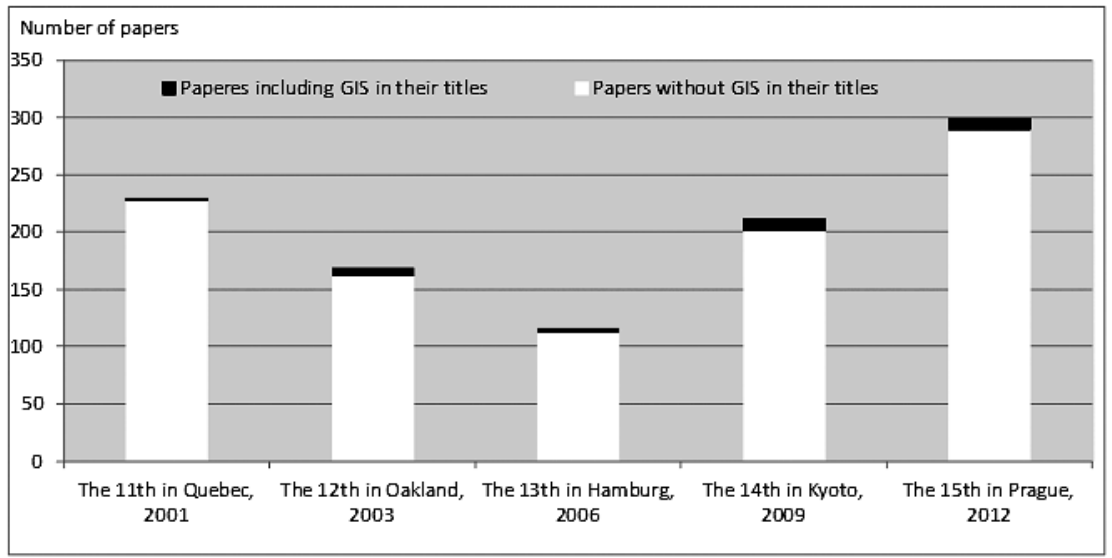

Figure 1. Papers presented at the International Conference of Historical Geographers Sources: Kawaguchi (2009b) and http://www.ichg2012.cz (last accessed 20 August 2012).

event. It is also necessary to construct a data mining methodology to facilitate the discovery of new data from historical materials using GIS. In order to overcome these two obstacles, cross collaboration across narrow fields of study is important.

Papers carrying GIS in the titles were first introduced at the 11th International Conference of Historical Geographers (ICHG), in 2001 (Figure 1). At the 14th conference hosted by Kyoto University in 2009 (the first meeting held in Asia), 9 per cent of the sessions dealt with digital humanities and historical GIS, while 5 per cent of the total number of papers included GIS in the titles. As of the beginning of the 21st century, ICHG registered a substantial increase of research works with GIS.

In order to speed up the progress of historical GIS, the Asia-Pacific countries support the GIS Center of the Academia Sinica, the Institute of Chinese Historical Geography at Fudan University, and the Center for Geographic Analysis of the Institute for Quantitative Social Science at Harvard University. Their excellent products -National Digital Archives Program (NDAP) in Taiwan and China Historical Geographic Information System (CHGIS) developed with Fudan University and Harvard University- are available on the Internet. The School of Information at the University of California, Berkeley and the Academia Sinica Computer Center in Taipei co-organized the Electronic Culture Atlas Initiative (ECAI) and the Pacific Neighborhood Consortium (PNC) to foster digital technology, especially historical GIS.

In Japan, GIS research institutes and academic societies were established since the 1990s: the Center for Spatial Information Science (CSIS) at the University of Tokyo (1998) and the Center for Integrated Area Studies (CIAS) at Kyoto University (2006), approved by the Ministry of Education, Culture, Sports, Science and Technology as Joint Usage Research Centers; the Geographic Information System Association of Japan (GISA) in 1992 and, in 2002, the JapanVietnam Geo-Informatics Consortium set up the International Conference on Geo-Informatics for Spatial-Infrastructure Development in Earth \& Allied Sciences (GIS-IDEAS). The Asian Network for GIS Studies-Japan (ANGIS-JAPAN) is being established in 2012. Since the year 2000, symposiums related to historical GIS have been held almost every year.

The increasing number of papers on ICHG, the establishment of new institutes and academic societies, as well as the frequency of symposiums, show that historical GIS is highly valued by computer scientists and specialists in the humanities, social sciences and historical geography. 
Encouraged by this positive trend, in 2005 Historical Geography prepared a special issue on historical GIS and several books were published in English (Knowles 2002; Gregory and Ell. 2007; Knowles 2008, etc.). In Japan, books on historical GIS started to appear from the beginning of this century (Kaneda et al. 2001; Okabe 2005; Uno 2006; Yano et al. 2007; Shibayama et al. 2008; Yano et al. 2011; Shibayama 2012; Japan Council for Historical GIS Research 2012; Yoshikoshi and Katahira 2012).

In order to reconstruct the lives of people in the past using GIS as a methodological tool, historical GIS (HGIS) researchers must undertake four important and urgent tasks (Kawaguchi 2009b) :

1. To propose a new framework for better understanding of the region, the local history, and the lives of people in the past, based on the discoveries with HGIS.

2. To collect, dispatch, and distribute relevant results from research works with HGIS.

3. To develop a four-dimensional HGIS architecture with longitude, latitude, elevation, and time axis, in order to fulfill spatio-temporal analysis.

4. To construct a digital-historical gazetteer with cross-reference functions between the names of places and their longitude/latitude, as well as an inter-local calendar conversion system.

These four tasks were already identified in the last decade of the 20th century, in the light of the rapid development of storage capacity and functions in computers and the Internet.

1. The aim of historical geographers is to find out how people organized their daily living space, and they collect their research results in "real world", "imagined world", and "abstract world". Methodical descriptions of the research process to obtain results can help create a new framework to better understand the region, local history and lives of people, and to develop information systems, including HGIS. This new information system for historical geography will allow: (i) to reduce data processing, (ii) to ensure data processing reliability, (iii) to preserve the historical materials in digital form, (iv) to share the data and data analysis methods with other researchers. It can also help researchers to systematize the methodology to visualize the spatio-temporal changes of landscape, environment and regional structures, and to carry out quantitative analysis to discover the underlying rules of living space.

"Real world" carries case studies of landscape reconstruction from historical maps, old photographs, satellite images, etc. (Ogata 2000; Hirai 2009 \& 2012; Yano et al. 2011; Nishimura and Kitamoto 2012; Yoshikoshi and Katahira 2012). Shibayama (2012) reconstructed urban transformation in Hanoi and proposed a new Area Informatics methodology in his book. The historical geography database of the Nara Basin project is developing a system to reconstruct the ancient landscape (Ideta 2012). Also the natural environment was reconstructed in Nara and Hanoi (Kawasumi 2012; Yonezawa 2009). The distribution of population and domestic migration were analyzed with HGIS (Arai and Koike 2005; Kawaguchi 2009a; Shinichi Takahashi and Nakagawa 2010; Nagata 2012; Kato and Kawaguchi 2012).

In "imagined world", Tsukamoto (2006, 2009 \& 2012) analyses the spatio-temporal changes in places of scenic interest in Kyoto with guidebooks and pictorial maps dating back to the 17th19th centuries. The next step will be to try to understand the mentality of the people in the past through the appearance and disappearance of notable places reflected in the presentation and distortions in old maps.

In "abstract world", several attempts were made to find out the underlying rules of regional structures. Mizoguchi (2012) discovered the core-periphery structure around the Nagoya castletown in the 18th and 19th centuries, which was proposed by G. W. Skinner. Ishizaki (2012) 
analyzed the spatial pattern of the central places in the Nara Basin in the 19th century.

2. In addition to the growth of HGIS research itself, it is also important to develop a complete system to store, open and share scientific information with HGIS. In a context of strong competition among the different media, researchers have to face a real challenge to make the result of their research work look appealing to the international academic community. Web HGIS has potential to become a more powerful and multiform medium than printed books or journals. There are many efforts to construct virtual museums, digital archives, and e-learning systems with Virtual Reality (VR), Computer Graphics (CG), and HGIS. New technologies such as Semantic Web construct ontology in the World Wide Web, and Linked Data connects many kinds of data with Semantic Web. Some HGIS projects may follow the steps of NDAP in Taiwan, which will transform its digital archive into an e-learning system. In Japan, the Virtual Kyoto Project at Ritsumeikan University promotes attractive touristic places in Kyoto (Yano et al. 2007).

3. Scientists in the humanities and social sciences should bear in mind GIS architecture when they use or construct HGIS, as it influences the way to process, combine and share information of historical materials. Before ESRI released ArcGIS 10 in 2010, it was difficult to analyze and visualize spatio-temporal transition with conventional GIS software. Only TimeMap, developed by Ian Johnson, could visualize spatio-temporal changes with the time bar function. In the last decade, computer experts in Japan started to develop outstanding next generation fourdimensional GIS architecture: Reki-Show Authoring Tool, by Hanashima et al. (2005); GLOBALBASE architecture, by Mori (H. Fujita and Mori 2012); HuTime/HuMap, with the collaboration of Kubo, Hara and Sekino (Kubo 2007; Kubo et al. 2010; Hara and Sekino 2012).

4. The digital-historical gazetteer and the inter-local historical calendar conversion system are essential resources for HGIS to shorten the process of drawing digital maps from historical materials. The Getty Thesaurus of Geographic Names Online and the Alexandria Digital Library Project Gazetteer Development are the leading digital gazetteers in the world. However, there is no cross-sectional gazetteer for countries that use Chinese characters. In Japan, some geocoding services are provided through the Internet. CSIS at the University of Tokyo offers a Geocoding service for CSV formatted files on WWW. Tani produced Geocoding and Mapping. Murayama constructed Gyosei Kukaku Hen'sen WebGIS and provides administrative boundary data since 1889 . Oketani (2012) released the Japanese Historical Gazetteer Database with Dai-Nihon Chimei Jisho (Gazetteer of Imperial Japan), Dai-Nihon Jiin Meikan (List of Buddhist temples in Japan), and old 1:50,000 maps. The Gaiho- $Z u$ Digital Archive Project will construct a digital gazetteer with old maps of neighbor countries, made by the former Japanese Imperial Army (Yamamoto and S. Kobayashi 2012). Aida (2007) provides an inter calendar conversion system for Japanese, Chinese and Western local-historical calendars. These useful contributions can support HGIS projects worldwide if we standardize the metadata of the digital gazetteer and calendar, develop the cross-sectional retrieval system, and set up a portal to access each system.

This condensed review shows that in Japan HGIS research on the four tasks mentioned above has well started in the first decade of the new millennium. As they are complementary and supplement each other, it is necessary to foster collaboration across specific fields of study and to systematize research methodology by sharing specific research topics, discussing the definition of the themes, finding ways to solve the problems, and consolidating the results in a single complete system. HGIS has potential to become a groundbreaking method for holistic evaluation, offering a new framework for better understanding of the region, the local history, 
and the lives of people in the past. It will also help overcome the divisions among the different narrow fields of study in the humanities and social sciences, including historical geography.

\section{Conclusion}

This brief review proves that, as of 1980, historical geography, including history of cartography and historical GIS, has achieved remarkable results in just over thirty years. If we take into consideration the three realms of historical geography as defined by $\mathrm{H}$. C. Prince in his work, in Japan it has been possible to collect a great number of case studies and monographs on landscape reconstruction in "real world" and, as of the 1980s, some geographers started to study historical maps and other materials in "imagined world". From the beginning of the new millennium, specialists have also started to undertake research works on historical GIS in "abstract world".

To begin with, in "real world" reconstruction of landscape or regional structure was the basic subject in historical geography in Japan because it was the main research theme before the 1980s. Particularly, since the 1980s, led by C. Kurosaki's pioneer paper (1983), modern historical geography has played an important role in helping understand how people and society evolved, and it established itself as a key platform to connect the past and the present world. We can distinguish two major new currents supporting progress in this field: environmental history and interdisciplinary communication. For instance, historical geographers presented some important viewpoints concerning environmental history with the help of archaeological data obtained on the excavation sites and studies on the relationship between geomorphologic environment and human agency in prehistoric, ancient and medieval periods. Other good examples are the research works on rural spatial territory, human adaptation to climate and geomorphologic environment, as well as subsistence economy without rice cultivation in medieval and early modern times. It is becoming increasingly important to take into account historical changes in the relationship between environment and human activity, in order to find more comprehensive answers to recent societal problems regarding the environment.

On the other hand, geographers, historians, and archaeologists can now share source materials and methodologies in historical geography to carry out interdisciplinary studies. In fact, old maps including medieval manor maps, early modern maps, and modern cadastral maps are no longer the exclusive property of historical geography. Many historians and archaeologists started to analyze historical maps in order to reconstruct landscape and cosmology in the past. Technical concepts such as landscape, regional structure, environment, cosmology, spatial perception, and spatial pattern are now shared with neighboring disciplines. In recent years, the outstanding expansion of modern historical geography dealing with industrial, economic and social modernization, as well as population, immigration and colonization, illustrates the vast and overflowing realm of historical geography, which overlaps with similar subjects also studied in neighboring disciplines. Therefore, in order to solve certain specific problems in research work, it is necessary to foster interdisciplinary collaboration across other specialized fields of study.

In "imagined world", semiotic, perceptual, and behavioral approaches were introduced and, since the 1980s, some historical geographers started to deal with subjects concerning the methodology to understand the spatial perception and behavior of people in the past. Illustrated 
old maps are particularly noteworthy in "imagined world", and a great number of case studies on historical cartography were established during the last three decades. Recent interdisciplinary communication with historians and archaeologists requires an alternative approach for better interpretation of historical maps. It is also necessary to find other materials and methods to improve analysis and understanding of the spatial perception by people in the past and their decision-making process regarding this matter.

In "abstract world", since the beginning of the 21 st century some attempts have been made to find out the underlying rules of regional landscape and spatial patterns with the help of historical GIS. If the computer experts succeed in developing four-dimensional HGIS architecture with longitude, latitude, elevation, and time axis, it would be possible to discover spatio-temporal patterns such as the dynamic central place theory or the dynamic Thünen model. In the meantime, it is already clear that HGIS has a great impact on the research works undertaken by the specialists in this field.

Stimulated by the valuable research works mentioned above, by the end of the 1970s the University of Tsukuba created the first major integrated course in historical geography comprising undergraduate and graduate studies. As of the 1980s, the graduate school conferred doctor's degrees to more than ten young scholars. Now in Japan lectures concerning historical geography are held in many faculties of humanities. During the last three decades, Japanese historical geographers have published some textbooks about the principles and essential aspects of historical geography, as well as a handbook and a glossary. This trend proves that, in Japan, historical geography has become a distinctive discipline in its own right within the humanities and social sciences.

Finally, reflecting on the future of historical geography, we would like to make a few remarks. In the light of the fruitful results obtained in "real world", "imagined world", and "abstract world", we think that it is important to develop a new original framework for better understanding of the region, the local history, and the life of people in the past so as to overcome the divisions among the different narrow fields of study. Historical GIS promises to become a key platform to integrate with spatio-temporal information the results of individual research in the humanities and social sciences, including historical geography.

Also, more Japanese historical geographers should communicate their research results in international conferences. The 14th International Conference of Historical Geographers (ICHG) held at Kyoto University, in August 2009, was a good opportunity for Japanese historical geographers to exchange views with researchers from other countries and to get acquainted with their methodologies. They should also submit more often articles in English for publication in international journals, bearing in mind that Web HGIS will become a more powerful platform than printed material to present the results of research work to the academic community throughout the world. In spite of the language barrier, communication is vital to undertake comparative studies on human activities in different parts of the world and thus propose a new framework for better understanding of human society.

\section{Postscript}

This review is written by six geographers: Prehistoric and Ancient Geography, by Shinji Miyamoto; Medieval Geography, by Hirotsugu Fujita; Early Modern Geography, by Taisaku Komeie; Modern Geography, by Norifumi Kawahara; History of Cartography, by Kazuyuki Onoda; Historical GIS, by Hiroshi Kawaguchi. The six geographers also collaborated in the 
Abstract, Introduction and Conclusion. We would be honored if this short review of Japanese historical geography could foster international cooperation among researchers in the humanities and social sciences, and historical geography from different countries.

\section{Notes}

1. The cho (neighborhoods), tsuji (crossroads), and Juraku-dai (the palace of Toyotomi Hideyoshi) of Kyoto are analyzed in Ashikaga (1984).

2. Concerning the former, the reviewer's ideas are in H. Fujita (2012). On the latter, see H. Fujita (2008).

3. Regarding trends in mapping history research in Britain and America since the 1980s, Hasegawa (1993) has elucidated important points.

4. Humanistic geography has become active since the 1970s. K. Yamori adopted such trend in historical cartography very early (1984, 1988 \& 1992). Kanasaka (1996) has summarized the contribution of Yamaori.

5. Regarding the interpretation of the iconography depicted on shoen estate picture maps, please see the research of Kuroda (1986 \& 2000).

6. 'The Siebold Collection Maps' Historical Lineage with Other Prefectural Maps in the Edo Era', (Japan Society for the Promotion of Science, Grant-in-Aid for Scientific Research (B), 2007-2009, No. 19320130).

7. Concerning the Arrowsmith World Map, Ninomiya (2007) also writes about the discovery of historical sources from within Japan.

8. The findings are recorded in The Historical Geographic Review [Rekishi Chirigaku Kiyo] (The Asociation of Historical Geographers in Japan, ed. 1979 \& 1985).

9. Kazutaka Unno's resaerch work is summarised by Hisatake et al. eds. (2007).

10. It is possible to access the products of Virtual Kyoto Project in following site. Ritsumeikan University. (2012) Virtual Kyoto. http://www.geo.lt. ritsumei.ac.jp/webgis/ritscoe.html (last accessed 13 October 2012).

11. It is possible to download the recent version of GLOBALBASE from the following site. GLOBAL-BASE PROJECT. (2012) GLOBALBASE. http://www.globalbase.org/ (last accessed 13 October 2012).

12. It is possible to download the recent version of HuTime/HuMap from the following site. The Humanities GIS Research Group (2012) The Humanities GIS Research Group http://www.h-GIS.org (last accessed 13 October 2012).

13. It is possible to use Geocoding service from the following site. The Center for Spatial Information Science at the University of Tokyo (2012) Geocoding Tools \& Utilities. http://newspat.csis.u-tokyo.ac.jp/geocode/ (last accessed 13 October 2012).

14. It is possible to use Geocoding and Mapping service from the following site. Tani Kenji Kenkyu-Shitsu. (2012) Geocoding and Mapping. http://ktgis. net/gcode/ (last accessed 13 October 2012).

15. The administrative boundary data since 1889 are provided from the following site. Murayama Yuji. (2012) Gyosei Kukaku Hensen WebGIS. http://giswin.geo.tsukuba.ac.jp/teacher/murayama/boundary/ (last accessed 13 October 2012).

\section{References}

Abe, K. (2012) The urban system of the modern Japan [Kindai Nihon no toshi taikei]. The Historical Geography (Rekishi Chirigaku) 54 (1) :14-24. (In Japanese)

Abe, Y. (2001) Employment policies toward Chinese workers and regional development in Sakhalin during the 1920s [1920nendai no Karahuto chiiki kaihatsu ni okeru Chugoku-jin rodosha koyo seisaku]. The Human Geography (Jimbun-Chiri) 53 (2):1-24. (In Japanese)

Akiyama, M., A. Kinda, Seiichi Takahashi, T. Mizoguchi, and M. Yamada, eds. (2008) Asian historical geographies, vol. 2: Urban and rural landscapes [Asia no rekishi-chiri 2: Toshi to nochi keikan]. Tokyo: Asakura Shoten. (In Japanese)

Akizuki, T. (1999) A history of exploration and cartography of the northwest pacific [Nihon-hokuhen no tanken to chizu no rekishi]. Sapporo: Hokkaido University Press. (In Japanese)

Aida, M. (2007) Constructing the ontology for historical calendars: for supporting the studies of Japanese classic literatures [Rekisho ontology no kochiku: Nihon kyureki jidai no bunken kenkyu shien no tameni]. Information Processing Society of Japan Technical Reports 2007 (95) :25-32. (In Japanese)

Amano, T. (1996) Research on reconstructing the plan of the interior precinct settlement of Osaka's Ishiyama Honganji-regarding location comparisons and interior structure [Osaka Ishiyama Hongan-ji jinai-machi plan no hukugen ni kansuru kenkyu: Ichi-hitei to naibu kosei wo megutte]. The Human Geography (Jimbun-Chiri) 48 (2) : 128-147. (In Japanese)

Amino, Y. (1976) Theory of medieval urbanism [Chusei toshi-ron]. Iwanami series on Japanese history 7 medieval 
period 3 [Iwanami koza Nihon rekishi7 chusei3], 253-303. Tokyo: Iwanami Shoten. (In Japanese)

Amino, Y. (1978) Separateness -The public world-Freedom [Muen Kugai Raku]. Tokyo: Heibonsha. (In Japanese)

Aoki, E. (1998) The trend of historical geography in Japan 1959-95 [Rekishi-chirigaku no keiko to henyo, Keisai ronbun ni miru rekishi-chirigaku no 40nen]. The Historical Geography (Rekishi Chirigaku) 40 (1) : 19-27. (In Japanese)

Aoyama, H. (2007) Space and knowledge in pre-modern maps [Zen-kindai chizu no kukan to chi]. Tokyo: Azekura Shobo. (In Japanese)

Arai, Y., and S. Koike (2005) A method for constructing a historical population-grid database from old maps and its applications. In GIS-based Studies in Humanities and Social Sciences, ed. A. Okabe, 71-83. London: Taylor \& Francis Group.

Arizono, S. (1986) A geographical study of early modern agronomical literatures [Kinsei nosho no chirigaku-teki ken$k y u]$. Tokyo: Kokon Shoin. (In Japanese)

Arizono, S. (1997) A regional study of indigenous agriculture [Zairai noko no chiiki kenkyu]. Tokyo: Kokon Shoin. (In Japanese)

Arizono, S., M. Endo, A. Onodera, E. Furuta, T. Mizoguchi, and T. Yoshida, eds. (2001) Handbook for historical geography surveys [Rekishi-chiri chosa handbook]. Tokyo: Kokon Shoin. (In Japanese)

Arizono, S. (2005) Agronomical technique in the early modern Tokai area [Kinsei Tokai chiiki no noko-gijutsu]. Tokyo: Iwata Shoin. (In Japanese)

Arizono, S. (2007a) Daily diets of common people in the Edo period: Were farmers not able to eat rice? [Kinsei shomin no nichijo-shoku: Hyakusho wa kome wo taberarenakatta ka?]. Otsu: Kaiseisha. (In Japanese)

Arizono, S. (2007b) A historical geography of agronomical technique [Noko gijutsu no rekishi-chiri]. Tokyo: Kokon Shoin. (In Japanese)

Ashikaga, K. (1984) A historical geography of the medieval and early modern city: On machi, suji, and zushi [Chukinsei toshi no rekishi-chiri: Machi, suji, zushi wo megutte]. Kyoto: Chijin Shobo. (In Japanese)

Ashikaga, K. (1995) Ancient Japanese space [Kosho nihon no kodai kukan]. Tokyo: Taimeido. (In Japanese)

Brown, P. C. (2011) Cultivating commons: Joint ownership of arable land in early modern Japan. Honolulu: University of Hawai'i Press.

Chiba, T. (1980) The milieu of Japanese folklore [Nihon minzoku hudo-ron]. Tokyo: Kobundo. (In Japanese)

Chiba, T. (1986) Mountain villages in the early modern era [Kinsei no sankan-sonraku]. Tokyo: Meicho Shuppan. (In Japanese)

Committee (2008) Preface [Jyo]. Journal of Historical Studies (Rekishigaku Kenkyu) 841 : 1. (In Japanese)

Cosgrove, D. and S. Daniels, eds. (1988) The iconography of landscape: Essays on the symbolic representation, Design and use of past environments. Cambridge: Cambridge University Press.

Endo, M. (1997) The Ainu as hunter-gatherers: A geographical study of residential mobility [Ainu to shuryo saishu shakai: Shudan no ryudosei ni kansuru chirigaku-teki kenkyu]. Tokyo: Taimeido. (In Japanese)

Fujii, J., M. Sugiyama, and A. Kinda, eds. (2007) Image of the great land: The world revealed by old maps [Daichi no shozo: Chizu ezu ga kataru sekai]. Kyoto: Kyoto University Press. (In Japanese)

Fujioka, K., K. Yamazaki, and K. Ashikaga, eds. (1981) Nihon rekishi-chiri yogo jiten [A glossary of historical geography of Japan]. Tokyo: Kashiwa Shobo. (In Japanese)

Fujioka, K., ed. (1983) Castle towns and their changes [Joka-machi to sono henbo]. Kyoto: Yanagihara Shoten. (In Japanese)

Fujioka, K., S. Minamide, K. Ideta, and H. Noma (1990) Revised historical geography [Shintei rekishi-chiri]. Tokyo: Taimeido. (In Japanese)

Fujita, H. (2008) Researches on the history of the medieval cities [Nihon chusei toshi-shi]. Architectural History (Kenchiku Shigaku) 50:100-115. (In Japanese)

Fujita, H. (2009) Ancient and medieval times as told in shoen estate picture maps [Shoen-ezu ga kataru Kodai/Chusei]. Tokyo: Yamakawa Shuppansha. (In Japanese)

Fujita, H. (2012) Urban-like places as seen geographically-searching for the 'city' in picture maps [Chirigaku kara mita toshi-teki na ba: Kaiga-shiryo ni 'toshi' keikan wo saguru]. Medieval urban research Vol. 17 Urban-like places [Chusei toshi kenkyu 17: Toshiteki na ba] ed. The Research Group of Medieval Cities, 73-90. Tokyo: Yoshikawa Kobunkan. (In Japanese)

Fujita, H., and H. Mori (2012) GLOBALBASE architecture and sharing the historical map base [GLOBALBASE architecture to rekishi chizu base no kyoyu]. In historical GIS perspectives in Japan: Landscape reconstruction, environment and regional structure [Rekishi GIS no chihei: Keikan, kankyo, chiikikozo no hukugen ni mukete]. ed. Japan Council for Historical GIS Research, 25-37. Tokyo: Bensei Shuppan. (In Japanese)

Fujita, Y. (1992) The making of mountain villages and forests in Oku-Mikawa [Oku-Mikawa sanson no keisei to rin' $y a]$. Tokyo: Meicho Shuppan. (In Japanese) 
Fujita, Y. (1995) The making of Japanese forestry regions [Nihon ikusei ringyo chiiki keisei-ron]. Tokyo: Kokon Shoin. (In Japanese)

Fujita, Y. (1998) The timberland Yoshino [Yoshino ringyo-chitai]. Tokyo: Kokon Shoin. (In Japanese)

Fukai, J. (1990) Map master Ochikochi Doin: Illustrated mapmaker of the Genroku period [Zuo Ochikochi Doin: Genroku no echi-zu sakusha]. Toyama: Katsura Shobo. (In Japanese)

Fukuda, T. (1986) Land reclamation in the early modern era and its origins [Kinsei shinden to sono genryu]. Tokyo: Kokon Shoin. (In Japanese)

Funakoshi, A. (1986) The acceptance of K'ang-hsi maps in Japan in the age of her isolation: A study of geographical history [Sakoku Nihon ni kita Koki-zu no chirigakushi-teki kenkyu]. Tokyo: Hosei University Press. (In Japanese)

Furuta, E. (1996) Regional development of the distribution of fish fertilizer in the early modern era [Kinsei gyohi ryutsu no chiiki-teki tenkai]. Tokyo: Kokon Shoin. (In Japanese)

Furuta, N. (2005) Environmental history of alluvial lowland [Heiya no kankyo-rekishigaku]. Tokyo: Kokon Shoin. (In Japanese)

Graduate School of Environmental Studies, Nagoya University, ed. (2008) The environmental histories of Europe and Japan: The Oxford-Kobe environment seminar. Nagoya: Graduate School of Environmental Studies, Nagoya University.

Gregory, I. N., and P. S. Ell (2007) Historical GIS: Technologies, methodologies and scholarship. Cambridge: Cambridge University Press.

Hamada, T. (2006) A cultural geography of folk ceramics [Mingei-undo to chiiki-bunka: Minto sanchi no bunka-chirigaku]. Kyoto: Shibunkaku Shuppan. (In Japanese)

Hanashima, M., K. Tomobe, and T. Hirayama (2005) Reki-show authoring tools: Risk, space, history. Journal of Systemics, Cybernetics and Informatics 3 (6):58-64.

Hara, S., and T. Sekino (2012) Development and usage of the spatio-temporal analysis tool HuTime/HuMap [Jikukan jyoho syori tool HuTime/HuMap no kaihatsu to riyo]. In historical GIS perspectives in Japan: Landscape reconstruction, environment and regional structure [Rekishi GIS no chihei: Keikan, kankyo, chiikikozo no hukugen ni mukete]. ed. Japan Council for Historical GIS Research, 13-24. Tokyo: Bensei Shuppan. (In Japanese)

Harada, Y. (2011) Historical geography of mine development in Japan: Before industrialization [Kinsei Nihon ni okeru kobutsu-shigen kaihatsu no tenkai: Sono chiiki-teki tenkai]. Tokyo: Kokon Shoin. (In Japanese)

Hasegawa, K. (1993) Contemporary trends in the history of cartography - iconology, context, and social history [Chizu-shi kenkyu no genzai: 1980nendai iko no Eibei no doko wo chushin ni]. The Human Geography (Jimbun-Chiri) 45 (2):40-60. (In Japanese)

Hasegawa, K., and K. Onoda (2010) Introduction to the special issue: Pictorial and modern maps in historical geography [Symposium shushi setsumei: Rekishi-chirigaku ni okeru ezu chizu ni yosete]. The Historical Geography (Rekishi Chirigaku) 52 (1) :1-3. (In Japanese)

Hashimoto, N. (2010) A natural environmental study on land development and landscape transition: In the case of Tone-river basin environment in early modern Japan [Kochi-kaihatsu to keikan no shizen-kankyogaku: Tonegawa ryuiki no kinsei kasen kankyo wo chushin ni]. Tokyo: Kokon Shoin. (In Japanese)

Hashimura, O. (2009) A social history of the use of fishing grounds: Fisheries, gathering, and territory in early modern southwest Kyushu [Gyojo riyo no shakai-shi: Kinsei seinan Kyushu ni okeru suisan shigen no hosai to territory]. Kyoto: Jimbun Shoin. (In Japanese)

Hattori, M. (1983) Historical study on Japanese ancient period (Ritsuryo) [Ritsuryo kokka no rekishi-chirigaku-teki kenkyu]. Tokyo: Taimeido. (In Japanese)

Hirai, S. (2009) Old maps and GIS [Kochizu to GIS]. In the third volume of GIS series; GIS for life and culture studies [The third volume of GIS series; Seikatsu bunka no tame no GIS]. eds. Murayama, Y., and R. Shibazaki, 171-184. Tokyo: Asakura Shoten. (In Japanese)

Hirai, S. (2012) GIS analysis on castle town planning maps in Sumoto [Sumoto-joka-ezu no GIS bunseki]. In historical GIS perspectives in Japan: Landscape reconstruction, environment and regional structure [Rekishi GIS no chihei: Keikan, kankyo, chiikikozo no hukugen ni mukete]. ed. Japan Council for Historical GIS Research, 109120. Tokyo: Bensei Shuppan. (In Japanese)

Hiraoka, A. (2003) Possession and management of Minami Torishima island: From catching albatross to getting guano and phosphate rocks [Minami Torishima no ryoyu to keiei: Ahodori kara chohun, rin-ko saishu he]. The Historical Geography (Rekishi Chirigaku) 45 (4) :1-14. (In Japanese)

Hisatake, T., K. Narumi, K. Tsutsumi, and S. Kobayashi (2007) Kazutaka Unno (1921-2006) and his works on the history of cartography [Unno Kazutaka sensei no kenkyu gyoseki to sono chizugaku-shi-teki igi]. Memoirs of Graduate School of Letters, Osaka University [Osaka Daigaku Daigakuin Bungaku Kenkyuka Kiyo] 47. 185234. (In Japanese) 
Historical Science Society of Japan, ed. (2008) Journal of Historical Studies (Rekishigaku Kenkyu) 841. (In Japanese) Ideta, K. (2012) Developing the database for historical geography in Nara basin and its utilization [Nara bonchi rekishi-chiri Database no kochiku to sono riyo]. In historical GIS perspectives in Japan: Landscape reconstruction, environment and regional structure [Rekishi GIS no chihei: Keikan, kankyo, chiikikozo no hukugen ni mukete]. ed. Japan Council for Historical GIS Research, 197-207. Tokyo: Bensei Shuppan. (In Japanese)

Iida, K. (2003) Historical geography of Japanese-Hawaiian [Hawai Nikkei-jin no rekishi-chiri]. Tokyo: Kokon Shoin. (In Japanese)

Ishihara, H., K. Kanasaka, S. Minamide, and T. Muto, eds. (2007) Asian historical geographies, vol. 1: Territory and move [Asia no rekishi-chiri 1, Ryoiki to ido]. Tokyo: Asakura Shoten. (In Japanese)

Ishikawa, T. (1997) Geographical study of the Japanese emigrant: Case study of Okinawa, Hiroshima and Yamaguchi, prefecture [Nihon-imin no chirigaku-teki kenkyu: Okinawa Hiroshima Yamaguchi]. Ginowan: Yoju Syorin. (In Japanese)

Ishizaki, K. (2012) The central place system in the Nara basin in the Meiji era [Meiji-ki no Nara bonchi ni okeru shuraku no cyushinsei]. In historical GIS perspectives in Japan: Landscape reconstruction, environment and regional structure [Rekishi GIS no chihei: Keikan, kankyo, chiikikozo no hukugen ni mukete]. ed. Japan Council for Historical GIS Research, 159-170. Tokyo: Bensei Shuppan. (In Japanese)

Ito, Takeshi (2003) The spatial history of cities [Toshi no kukan-shi]. Tokyo: Yoshikawa Kobunkan. (In Japanese)

Ito, Toshikazu (1998) Historical geographical research on 'inside the ditch' areas in medieval eastern Japan- the case of the northern Kanto [Chusei Togoku no 'Hori no uchi' gun ni kansuru rekishi-chirigaku-teki kenkyu]. The Historical Geography (Rekishi chirigaku) 40:63-80. (In Japanese)

Ito, Toshikazu (2000) Historical geographical research on 'mountain fields (burnt fields)' in Kii province [Kiinokuni no 'Yamahata (Yakihata)' ni kansuru rekishi-chirigaku-teki kenkyu]. En marge de l'histoire (Shikyo) 41: 1-24. (In Japanese)

Ito, Y. (1994) A milieu of thought on flood and river control [Chisui-shiso no hudo: Kinsei kara gendai he]. Tokyo: Kokon Shoin. (In Japanese)

Ito, Y. (2010) Flood and people: A dialectic history [Kozui to ningen: Sono sokoku no rekishi]. Tokyo: Kokon Shoin. (In Japanese)

Iwahana, M. (1992) A historical geography of the Dewa-sanzan belief [Dewa-sanzan shinko no rekishi-chirigaku-teki kenkyu]. Tokyo: Meicho Shuppan. (In Japanese)

Iwahana, M. (2003) Concentric structure of the Dewa-sanzan belief [Dewa-sanzan shinko no ken-kozo]. Tokyo: Iwata Shoin. (In Japanese)

Iwasaki, K. (1999) A study of the cotton belt in early modern Tokai [Kinsei Tokai mensaku chiiki no kenkyu]. Tokyo: Taimeido. (In Japanese)

Japan Council for Historical GIS Research, ed. (2012) Historical GIS perspectives in Japan: Landscape reconstruction, environment and regional structure [Rekishi GIS no chihei: Keikan, kankyo, chiikikozo no hukugen ni mukete]. Tokyo: Bensei Shuppan. (In Japanese)

Kajikawa, Y. (1997) A historical geography of early modern Owari [Kinsei Owari no rekishi-chiri]. Kanazawa: Kikakushudan NAF. (In Japanese)

Kanai, T. (2004) Historical geographical research on temple precinct settlements [Jinai-machi no rekishi-chirigaku-teki kenkyu]. Osaka: Izumi Shoin. (In Japanese)

Kanasaka, K. (1996) A complete bibliography of works by Dr. Kazuhiko Yamori and some comments on his geographical studies [Yamori Kazuhiko no chosaku mokuroku to chirigaku kenkyu]. Memoirs of the Faculty of Literature, Osaka University [Osaka Daigaku Bungakubu Kiyo] 36:65-123. (In Japanese)

Kaneda, A., H. Tsumura, and I. Niiro (2001) Introduction to GIS for Archeological Studies [Kokogaku no tame no GIS nyumon]. Tokyo: Kokon Shoin. (In Japanese)

Kato, M. (2002) Slum and white way in Osaka [Osaka no slum to sakariba]. Osaka: Sogensha. (In Japanese)

Kato, T., and H. Kawaguchi (2012) Trial to develop a HGIS for analyzing the domestic migration in the Edo period [Edo jidai ni okeru jinko ido bunseki system no shisaku]. In historical GIS perspectives in Japan: Landscape reconstruction, environment and regional structure [Rekishi GIS no chihei: Keikan, kankyo, chiikikozo no hukugen ni mukete]. ed. Japan Council for Historical GIS Research, 149-158. Tokyo: Bensei Shuppan. (In Japanese)

Kawaguchi, H. (1990) Historical geography of modern Japan: A study of geographical studies in Japan 1989 [Gakkai tebnbo: Rekishi-Chiri · Kindai]. The Human Geography (Jimbun-Chiri) 42 (3):273-275. (In Japanese)

Kawaguchi, H. (1996) Population increase policy after the 1783 great famine in northeastern Tokugawa Japan. Annales de Démographie Historique 1996:151-168.

Kawaguchi, H. (2009a) A data analysis system for population and family studies on Japan in the 17th-19th centuries. Japanese Journal of Human Geography (Jimbun Chiri) 61 (6) :2-22. 
Kawaguchi, H. (2009b) Conference report from the symposium on the perspective of the historical GIS at Tezukayama University ['Historical GIS no chihei' symposium kara]. The Journal of Information Science and Technology Association [Joho no Kagaku to Gijutsu] 59 (11):545-550. (In Japanese)

Kawamura, H. (1984) Study of Kuni-ezu compiled by the Tokugawa shogunate [Edo-bakufu-sen kuni-ezu no ken$k y u]$. Tokyo: Kokon Shoin. (In Japanese)

Kawamura, H. (1992) Early modern illustrated maps and surveying techniques [Kinsei ezu to sokuryo-jutsu]. Tokyo: Kokon Shoin. (In Japanese)

Kawasumi, T. (2012) Reconstruction of ancient topography and quantitative analysis of urban district in Heijyo-Kyo with GIS [GIS wo mochiita Heijyo-Kyo no kochikei no teiryoteki fukugen to shigaichi no ricchi bunseki]. In historical GIS Perspectives in Japan: Landscape reconstruction, environment and regional structure [Rekishi GIS no chihei: Keikan, kankyo, chiikikozo no hukugen ni mukete]. ed. Japan Council for Historical GIS Research, 209-219. Tokyo: Bensei Syuppan. (In Japanese)

Kikuchi, K. (1980) Historical disaster in Japan: A verification through the Buddhist register of deaths in the late Edo period [Nihon no rekishi-saigai: Edo-koki no jiin-kakocho ni yoru jissho]. Tokyo: Kokon Shoin. (In Japanese)

Kikuchi, K., ed. (1987) A social history of early modern cities [Kinsei toshi no shakai-shi]. Tokyo: Meicho Shuppan. (In Japanese)

Kikuchi, T. (1977) Methodology of historical geography [Rekishi-chirigaku hohoron]. Tokyo: Taimeido. (In Japanese)

Kikuchi, T. (1984) An historical geography of Japan [Nihon Rekishi-chiri Gaisetsu]. Tokyo: Kokon Shoin. (In Japanese)

Kikuchi, T. (1986) Land reclamation in the early modern era, the sequel volume: Case studies [Zoku shinden-kaihatsu: Jirei-hen]. Tokyo: Kokon Shoin. (In Japanese)

Kikuchi, T. (1987) Methodology of historical geography [Rekishi-chirigaku hohoron], revised edition. Tokyo: Taimeido. (In Japanese)

Kinda, A. (1985a) A Historical-geographical study of the Jori plan and the rural landscape [Jori to sonraku no rekishi-chirigaku kenkyu]. Tokyo: Taimeido. (In Japanese)

Kinda, A. (1985b) A historical geography of Australia: The urban and rural grid pattern plans [Australia rekishi chiri: Toshi to nochi no hokaku plan]. Kyoto: Chijin Shobo. (In Japanese)

Kinda, A. (1993) Ancient Japanese landscape [Kodai Nihon no keikan]. Tokyo: Yoshikawa Kobunkan. (In Japanese)

Kinda, A. (1995) Plans and structure of Kokufu provincial capitals [Kokufu no keitai to kozo ni tsuite]. Bulletin of the National Museum of Japanese History [Kokuritsu Rekishi-Minzoku hakubutsukan kenkyu hokoku] 63:83132. (In Japanese)

Kinda, A. (1997) Some traditions and methodologies of Japanese historical geography. Journal of Historical Geography $23: 62^{-75}$.

Kinda, A. (1998) Ancient Shoen-ezu and landscape [Kodai Shoen-ezu to keikan]. Tokyo: University of Tokyo Press. (In Japanese)

Kinda, A. (2001) The concept of 'townships' in Britain and the British colonies in the seventeenth and eighteenth centuries. Journal of Historical Geography 27 (2) : 137-152.

Kinda, A., ed. (2007) Heiankyo-Kyoto: City plans and urban structure [Heiankyo-Kyoto: Toshizu to toshikozo]. Kyoto: Kyoto University Press. (In Japanese)

Kinda, A., ed. (2010) A landscape history of Japan. Kyoto: Kyoto University Press.

Kinda, A., T. Komeie, S. Minamide, T. Mizoguchi, and K. Uesugi, eds. (2010) Proceedings of the $14^{\text {th }}$ International Conference of Historical Geographers, Kyoto 2009. Kyoto: Kyoto University Press.

Kitamura, T. (1981) Historical development of early modern reclamation and a question of land [Shinden-sonraku no shiteki tenkai to tochi-mondai]. Tokyo: Iwanami Shoten. (In Japanese)

Kitamura, T. (1990) A study of the basic structure of Japanese rural villages: The process of development [Nihon noson no kisokozo kenkyu: Sono tenkai katei]. Kyoto: Chijin Shobo. (In Japanese)

Knowles, A. K., ed. (2002) Past time, Past place: GIS for history. Redlands: ESRI Press.

Knowles, A. K., ed. (2008) Placing history: How maps, spatial data, and GIS are changing historical scholarship. Redlands: ESRI Press.

Kobayashi, K. (1985) A study of castle towns in the Sengoku era [Sengoku jokamachi no kenkyu]. Tokyo: Taimeido. (In Japanese)

Kobayashi, K. (1986) Class divisions in the marketplace in Niimi-no-sho in Bicchu province [Bicchu-no-kuni Niimino-sho ni okeru ichiba no kaiso bunka]. Human geography's field of view [Jimbun-chirigaku no shiken]. ed. Professor Suizu Ichiro's retirement commemorative project society, 307-318. Tokyo: Taimeido. (In Japanese)

Kobayashi, K. and A. Kinda (1988) Research frontiers in the historical geography of Japan in 1978-1987. Geographical Review of Japan, Series B, 61 (1):78-98.

Kobayashi, S. (2003) Agriculture, landscape and disaster: An environmental history of the Ryukyu Archipelago 
[Noko, keikan, saigai: Ryukyu-retto no kankyo-shi]. Tokyo: Daiichi Shobo. (In Japanese)

Kobayashi, S. (2006) The map making of modern Japan in relation to East Asian countries: A perspective on the study of Japanese military and colonial maps [Kindai Nihon no chizu sakusei to Higashi-Ajia: Gaiho-zu kenkyu no tenbo]. E-journal GEO 1 (1). 52-66. (In Japanese)

Komeie, T. (2002) Landscape and structure of mountain villages in the medieval and early modern eras [Chu-kinsei sanson no keikan to kozo]. Tokyo: Azekura Shobo. (In Japanese)

Komeie, T. (2012) A spatial implication of the concept of the modern era: Views and perspectives on modern historical geographies ['Kindai' gainen no kukan-teki gani wo megutte: Modern historical geography no shiza to tenbo]. The Historical Geography (Rekishi Chirigaku) 54 (1):68-83. (In Japanese)

Konagaya, Y., T. Nakasato, and Y. Fujita, eds. (2007) Asian historical geographies, vol. 3: Forest, grassland, and water [Asia no Rekishi-chiri 3: Rin'ya, Sogen, Suiiki]. Tokyo: Asakura Shoten. (In Japanese)

Kono, K. (2012) The trends and issues in historical geographic studies on Japanese modern age: The case after 1980s [Kindai rekishi-chiri kenkyu no doko to kadai: 1980nendai iko wo chushin to shite]. The Historical Geography (Rekishi Chirigaku) 54 (1):5-13. (In Japanese)

Koyama, Y., M. Shimosaka, and T. Yoshida, eds (1997) Collection of medieval estate picture maps [Chusei Shoen-ezu taisei]. Tokyo: Kawade Shobo Shinsha. (In Japanese)

Kubo, M. (2007) Proposal of archiving cultural resources with spatiotemporal information [Jikukan joho wo kye to suru bunkashigen archivus no koso]. In Current Awareness (294) : 24-27. Tokyo: National Diet Library. (In Japanese)

Kubo, M., S. Hara, and T. Sekino (2010) Three-dimensional spatiotemporal model and its application to analysis of research resources: Toward constructing historical knowledge [Sanjigen jikukan model to sono tenkai: Rekishi chishiki wo kochiku suru tameni]. Journal of the Japanese Society for Artificial Intelligence (Jinko Chino Gakkai Shi) 25 (1) (Special Issue: Historical Knowledge-Based Science) : 50-55. (In Japanese)

Kuroda, H. (1986) The medieval period as a frontier and as a symbol [Kyokai no chusei shocho no chusei]. Tokyo: University of Tokyo Press. (In Japanese)

Kuroda, H. (2000) The science of interpreting illustrated maps of medieval proprietary estates [Chusei-shoen-ezu no kaishakugaku]. Tokyo: University of Tokyo Press. (In Japanese)

Kuroda, H., M. E. Berry, and F. Sugimoto, eds. (2001) Mapping and politics in premodern Japan [Chizu to ezu no seiji-bunka-shi]. Tokyo: University of Tokyo Press. (In Japanese)

Kurosaki, C. (1983) The problems of modernization in historical geography〔Kaidai ni kaete: Hitotsu no ganbouteki tenbou], The Historical Geographic Review (Rekishi Chirigaku Kiyo) 25:5-20. (In Japanese)

Kusaka, M. (1980) The topographic conditions in the historical age [Rekishi jidai no chikei kankyo]. Tokyo: Kokon Shoin. (In Japanese)

Kusaka, M. (1991) Reconstruction of ancient landscape [Kodai keikan no fukugen]. Tokyo: Chuokoron-sha. (In Japanese)

Miki, K. (2010) The Mitsumine belief and its regional foundation [Mitsumine shinko no tenkai to chiiki-teki kiban]. Tokyo: Kokon Shoin. (In Japanese)

Miki, M. (2003) The formation of the Korean community in inter-war Karafuto (Sakhalin) [Senkan-ki Karafuto ni okeru Chosen-jin shakai no keisei: 'Zainichi' chosen-jin-shi kenkyu no kukan-sei wo megutte]. Socio Economic History (Shakai Keizai Shigaku) 68 (5) :25-46. (In Japanese)

Miura, T. (1983) Land reclamation in the early modern Akita Domain: A geographical study [Akita-han ni okeru shinden kaihatsu: Sono chirigaku-teki kenkyu]. Tokyo: Kokon Shoin. (In Japanese)

Miya, N. (2007) Maps tell the story: A world map created by the Mongol Empire [Chizu wa kataru: Mongoru-teikoku ga unda sekai-zu]. Tokyo: Nikkei Publishing Inc. (In Japanese)

Mizoguchi, T. (2002) A regional history of the Japanese dry field area from the early modern era to the modern era [Nihon kinsei kindai no hatasaku chiiki-shi kenkyu]. Nagoya: Nagoya University Press. (In Japanese)

Mizoguchi, T. (2012) Core-periphery structure in the Owari plain during the 17th-19th centuries [17-19seiki no Owari heiya ni okeru chusin to syuhen]. In historical GIS perspectives in Japan: Landscape reconstruction, environment and regional structure [Rekishi GIS no chihei: Keikan, kankyo, chiikikozo no hukugen ni mukete]. ed. Japan Council for Historical GIS Research, 227-237. Tokyo: Bensei Shuppan. (In Japanese)

Mizuta, Y. (1978) Reconsideration of the form of temple precinct settlements [Jinai-machi no keitai saiko]. Historical Geography Association Research Reports (Rekishi Chirigakkai Kaiho) 96:15-26. (In Japanese)

Mizuuchi, T., ed. (2006) Series human geography, volume 8: History and space [Series jimbun-chirigaku 8: Rekishi to kukan]. Tokyo: Asakura Shoten. (In Japanese)

Mori, M. (2005) Modernity in Shikoku pilgraimage: From "modern pilgrimage" to "healing journey" [Shikoku Henro no kingendai: "Modern henro" kara "iyashi no tabi" made]. Osaka: Sogensha. (In Japanese)

Nagano, T. (1987) A historical geography of the Shugendo belief of Hikosan [Hikosan Shugendo no rekishi-chirigaku- 
teki kenkyu]. Tokyo: Meicho Shuppan. (In Japanese)

Nagata, Y. (2012) The process of the development of the modern villages in the basin of the Songkram river in the northeastern Thai [Tohoku Thai no Songkhram gawa ryuiki ni miru gendai kaitaku noson no keisei katei]. In historical GIS perspectives in Japan: Landscape reconstruction, environment and regional structure [Rekishi GIS no chihei: Keikan, kankyo, chiikikozo no hukugen ni mukete]. ed. Japan Council for Historical GIS Research, 137-145. Tokyo: Bensei Shuppan. (In Japanese)

Nakano, E. (1989) Jori plan in Kii [Kii-no-kuni no jori]. Tokyo: Kokon Shoin. (In Japanese)

Narumi, K. (2007) Indigenous land surveying techniques and their diffusion process in early modern Japan [Kinsei Nihon no chizu to sokuryo]. Fukuoka: Kyushu University Press. (In Japanese)

Ninomiya, R. (2007) Takahashi Kageyasu and the Shintei Bankoku Zenzu: The newly discovered Arrowsmith map [Takahashi Kageyasu to Shintei-Bankoku-Zenzu: Shinhakken no Arrowsmith-hozu]. Sapporo: Hokkaido publication project center. (In Japanese)

Nishimura, Y., and A. Kitamoto (2012) Reconstruction of the landscape in Beijing with the imperial capital map during the days of Qianlong and old photographs [Kenryu Keijyou Zen-zu to ko-syashin wo mochiita Peking ko-keikan no saigen]. In historical GIS perspectives in Japan: Landscape reconstruction, environment and regional structure [Rekishi GIS no chihei: Keikan, kankyo, chiikikozo no hukugen ni mukete]. ed. Japan Council for Historical GIS Research, 95-107. Tokyo: Bensei Shuppan. (In Japanese)

Nishioka, T., ed. (1976) Collection of Japanese feudal estate picture maps, Vol. I [Nihoni Shoen-ezu shusei (Jyo)]. Tokyo: Tokyodo Shuppan. (In Japanese)

Nishioka, T., ed. (1977) Collection of Japanese feudal estate picture maps, Vol. II [Nihoni Shoen-ezu Shusei (Ge)]. Tokyo: Tokyodo Shuppan. (In Japanese)

Nito, A., ed. (2001) The study on ancient Shoen map and the depicted society; The analysis of the map of Nukatadera and its vicinity [Kodai Shoen-ezu to zaichi shakai ni tsuite no shi-teki kenkyu]. Bulletin of the National Museum of Japanese History. [Kokuritsu Rekishi-Minzoku hakubutsukan kenkyu hokoku] 88:1-469. (In Japanese)

Noma, H. (2009) A historical and ecological system of lowlands: A comparative study of Japanese rice societies [Teichi no rekishi-seitai-system: Nippon no hikaku inasaku shakai-ron]. Suita: Kansai University Press. (In Japanese)

Ogata, N. (2000) A study of the city planning system of the ancient Bo-hai state using satellite photos [Eisei shashin wo riyo shita Bokkai-tojo plan no kenkyu]. The Human Geography (Jimbun-Chiri) 52 (2) : 19-38. (In Japanese)

Okabe, A., ed. (2005) GIS-based studies in humanities and social sciences. London: Taylor \& Francis Group.

Oketani, I. (2012) Constructing a database of maps and place names [Chizu chimei database no kochiku]. In historical GIS perspectives in Japan: Landscape reconstruction, environment and regional structure [Rekishi GIS no chihei: Keikan, kankyo, chiikikozo no hukugen ni mukete]. ed. Japan Council for Historical GIS Research, 7988. Tokyo: Bensei Syuppan. (In Japanese)

Ono, T. (1986) Archaeological geography in Japan [Nihon koko-chiri-gaku kenkyu]. Tokyo: Taimeido. (In Japanese)

Onodera, A. (1991) Classification and examination of river maps of the edo period [Kinsei kasen-ezu no kenkyu]. Tokyo: Kokon Shoin. (In Japanese)

Oshiro, N. (2012) Rethinking genealogy place: On an alternative reading of landscape [Basho no keifugaku saiko: Aruiwa hukei no betsu no yomikata ni tsuite]. The Historical Geography (Rekishi Chirigaku) 54 (1): 30-38. (In Japanese)

Otobe, J. (2005) The characteristic of sites of foreign companies in Yokohama during the open port period, 19681900: Based directory [Yokohama kyoryuchi ni okeru jigyosho no ricchi-tokusei: Directory no bunseki kara]. The Historical Geography (Rekishi Chirigaku) 47 (3) :24-45. (In Japanese)

Ouji, T. (2007) Maps tell the story: The birth of world maps [Chizu wa kataru: Sekai-chizu no tanjyo]. Tokyo: Nikkei Publishing Inc. (In Japanese)

Prince, H. C. (1971) Real, imagined, and abstract worlds of the past. Progress in Human Geography 3:1-86.

Research Group of the Illustrated Map of Katsuragawa, ed. (1982) Space-recognition and its expression in 'The illustrated map of Katsuragawa' ['Katsuragawa-ezu' ni miru kukan-ninshiki to sono hyogen]. Journal of Japan (Nihonshi Kenkyu) 244:34-51. (In japanese)

Research Group of the Illustrated Map of Katsuragawa, ed. (1988) Cosmology of illustrated maps Vol. 1 [Ezu no cosmology (Jyo) ]. Kyoto: Chijin Shobo. (In Japanese)

Research Group of the Illustrated Map of Katsuragawa, ed. (1989) Cosmology of illustrated maps Vol. 2 [Ezu no cosmology $(\mathrm{Ge})$ ]. Kyoto: Chijin Shobo. (In Japanese)

Research Group of the Kuni-ezu, ed. (2005) Kuni-ezu; Province maps of Japan made by the Tokugawa government [Kuni-ezu no sekai]. Tokyo: Kashiwa Shobo. (In Japanese) 
Sano, S. (2008) An environmental history of villages and watersides in the medieval and early modern eras [Chukinsei no sonraku to mizube no kankyo-shi]. Tokyo: Yoshikawa Kobunkan. (In Japanese)

Sekido, A. (2012) Modernity as depicted in bird's eye views: A case of Kusatsu spa [Chokan-zu ni miru kindai: Kusatsu onsen wo jirei to shite]. The Historical Geography (Rekishi Chirigaku).54 (1) :39-53. (In Japanese)

Senda, M. (1991) An historical geography of ancient Japan [Kodai Nihon no rekishi-chirigaku-teki kenkyu]. Tokyo: Iwanami Shoten. (In Japanese)

Senda, M. (1992) Composition of landscape: A geographical sketch [Fukei no kozu: Chiriteki sobyo]. Kyoto: Chijin Shobo. (In Japanese)

Senda, M. (1996) An archaeology of landscape [Fukei no kokogaku]. Kyoto: Chijin Shobo. (In Japanese)

Senda, M. (2004) Space of kingship in ancient Japan [Kodai Nihon no oken-kukan]. Tokyo: Yoshikawa Kobunkan. (In Japanese)

Shibayama, M., S. Hara, and T. Kishi, eds. (2008) Creating the area informatics [Chiki-johogaku no soshutsu: Asia yugaku 113]. Tokyo: Bensei Shuppan. (In Japanese)

Shibayama, M. (2012) South East Asia with the area informatics and mapping [Chiiki-joho mapping kara yomu Tonan Asia]. Tokyo: Bensei Shuppan. (In Japanese)

Sugimoto, F., K. Isonaga, A. Onodera, Toby Ronald P., H. Nakano, and S. Hirai, eds. (2011) Ezu, society, and the world: An introduction to early-modern Japanese maps [Ezugaku nyumon]. Tokyo: University of Tokyo Press. (In Japanese)

Sugiura, T. (2011) Ethnic geography [Ethnic chirigaku]. Tokyo: Gakujutsu Shuppankai. (In Japanese)

Takagi, T. (2011) Research on maps of the northern region in early modern Japan [Kinsei Nihon no hoppo-zu ken$k y u$ ]. Sapporo: Hokkaido publication project center. (In Japanese)

Takahashi, Y. (1995) Ancient traffic archaeological study in Japan [Kodai kotsu no koko-chiri]. Tokyo: Taimeido. (In Japanese)

Takahashi, M. (2003) Environmental archaeology in alluvial plain [Heiya no kankyo-kokogaku]. Tokyo: Kokon Shoin. (In Japanese)

Takahashi, Seiichi (1994) Ancient city study in Japan [Kodai Nihon toshi kenkyu]. Tokyo: Kokon Shoin. (In Japanese)

Takahashi, Shinichi, and S. Nakagawa, eds. (2010) The demographic transition in Japan from the view of local population [Ciiki jinko kara mita Nihon no jinko tenkan]. Tokyo: Kokon Shoin. (In Japanese)

Tanaka, Tatsuya (2011) Field reclamation and the society of the villages in the eastern provinces during the period of transition from the medieval to the early modern period [Chu-kinsei iko-ki ni okeru togoku sonraku no kaihatsu to shakai]. Tokyo: Kokon Shoin. (In Japanese)

Tanaka, Tomohiko (2004) People and roads around holy places [Seichi wo meguru hito to michi]. Tokyo: Iwata Shoin. (In Japanese)

Tawa, M. (2006) Stone tidal weir fishing in the Penghu island, Taiwan, in the early 1910s [1910nendai ni okeru Houko-retto hokubu no ishihimi gyogyo: Taiwan-Sotoku-fu bunsho suhu gyogyo-ken shinsei shorui no bunseki wo tsujite]. Japanese Journal of Human Geography (Jimbun Chiri) 58 (1) :73-90. (In Japanese)

The Association of Historical Geographers in Japan, ed. (1979) Maps and historical geography [Chizu to rekishi-chiri] (The Historical Geographic Review No. 21). (In Japanese).

The Association of Historical Geographers in Japan, ed. (1985) Spatial awareness and historical geography [Kukan ninchi no rekishi-chiri] (The Historical Geographic Review No. 21). (In Japanese)

The Association of Historical Geographers in Japan, ed. (2010) Special issue: Reevaluating old maps as tools for the study of historical geography [Rekishi-chirigaku ni okeru ezu chizu]. The Historical Geography (Rekishi Chirigaku) 52 (1). (In Japanese)

The Association of Historical Geographers in Japan, ed. (2012) Special issue: Rethinking modern historical geography in Japan [Kindai no rekishi-chiri saiko]. The Historical Geography (Rekishi Chirigaku) 54 (1). (In Japanese)

Toyama, S. (2006) Environmental reconstruction in archaeological site [Iseki no kankyo fukugen]. Tokyo: Kokon Shoin. (In Japanese)

Tsuchida, R. (1994) A historical geography of official stations in the early modern highways [Kinsei shuku-eki no rekishi-chirigaku-teki kenkyu]. Tokyo: Yoshikawa Kobunkan. (In Japanese)

Tsuchida, R. (2001) Governmental control and highways in early modern Japan [Kinsei Nihon no kokka shihai to kaido]. Tokyo: Bunken Shuppan. (In Japanese)

Tsukamoto, A. (2006) Spatial distribution of sights in historical guidebooks and its changes over time: The case of Kyoto, Japan 16C-18C [Kinsei Kyoto no meisho-annai-ki ni egakareta ba no kukan-teki bunpu to sono rekishiteki hensen]. Theory and Applications of GIS [GIS riron to oyo] 14 (2):41-52. (In Japanese)

Tsukamoto, A. (2009) Unfolding the landscape drawing method of Rakuchu-rakugai-zu screen paintings in a GIS

$$
-25-
$$


environment. International Journal of Humanities and Arts Computing 3 (1-2): 39-60.

Tsukamoto, A. (2012) Space in the printed town maps in early modern Kyoto [Kinsei Kyoto no kanko toshi-zu ni egakareta kukan]. In historical GIS perspectives in Japan: Landscape reconstruction, environment and regional structure [Rekishi GIS no chihei: Keikan, kankyo, chiikikozo no hukugen ni mukete]. ed. Japan Council for Historical GIS Research, 121-130. Tokyo: Bensei Shuppan. (In Japanese)

Uesugi, K. (2010) Edo period intellectuals and maps [Edo chishiki-jin to chizu]. Kyoto: Kyoto University Press. (In Japanese)

Unno, K. (2003) Monographs on the history of cartographical exchange between the East and West [Tozai-bunka kosho-shi kenkyu]. Osaka: Seibundo Shuppan. (In Japanese)

Unno, K. (2004) Monographs on the history of geography in the East (Volume on Continental Asia societies) [Toyo chirigaku-shi kenkyu (Tairiku-hen)]. Osaka: Seibundo Shuppan. (In Japanese)

Unno, K. (2005) Monographs on the history of geography in the East (Volume on Japanese society) [Toyo chirigakushi kenkyu (Nihon-hen)]. Osaka: Seibundo Shuppan. (In Japanese)

Unno, K. (2010) The Kuang-yü-t'u in the cultural history of Chinese maps [Chizu bunkashijyo no Koyo-zu (Library of Toyo bunko 73)]. Tokyo: Toyo Bunko. (In Japanese)

Uno, T., ed. (2006) Practice of archeological GIS: Reading the historical space with advanced technology [Jissen kokogaku GIS: Sentan-gijutsu de rekishi kukan wo yomu]. Tokyo: NTT Shuppan. (In Japanese)

Ushizaki, Y. (2005) Characteristic and use of fire insurance map as large-scale maps in the Showa period [Showashoki ni okeru dai-shukushaku-chizu to siteno kasai-hoken tokushyoku-chizu no tokushoku to sono riyo]. The Historical Geography (Rekishi Chirigaku) 47 (5) : 1-16. (In Japanese)

Washizaki, S. (2012) The history of interdisciplinary research between socio-economics history and historical geography: Trend and issues [Rekishi-chirigaku: Nihon keizai-shi kan no gakusai-teki kenkyu-shi: Susei to kadai]. The Historical Geography (Rekishi Chirigaku) 54 (1):58-67. (In Japanese)

Watanabe, R. (2008) People and control of the samurai dwelling areas in early modern Japan [Kinsei bukechi no jumin to yashiki-kanri]. Suita: Osaka University Press. (In Japanese)

Wigen, K. (1995) The making of a Japanese periphery, 1750-1920. Berkeley: University of California Press.

Yagasaki, N. (1993) Japanese emigrant society of California [California no Nihon-jin iminsyakai]. Tokyo: Kokon Shoin. (In Japanese)

Yamamoto, T. (2000) Spatial changes in a suburban area of a local Korean city under Japanese rule: Ch'eongju city in North Ch'ungch'eong province [Nihon tochi jidai ni okeru Kankoku chiho toshi kogai kukanteki henyo: Chunchon pukudo Chonju no jirei]. Geographical review of Japan (Chirigaku Hyoron) 73 (12) : 855-874. (In Japanese)

Yamamoto, T. (2001) Changes in Korean rural villages under the Japanese rules - analyzing the cadastres and cadastral maps in Kangodong-myun, Kyungji city [Nihon tochi jidai ni okeru Kankoku no noson-chiiki no henyo: Kyonju shi kangodon-myon ni okeru chiseki-shiryo no bunseki wo chushin ni]. The Human Geography (Jimbun-Chiri) 53 (2):25-50. (In Japanese)

Yamamoto, T. (2003) Spatial changes in Mok-po city and the neighboring district in Korean peninsula under Japanese rule: Analyzing the cadastres and cadastral maps [Nihon tochi jidai ni okeru Chosen hanto Moppo-hu syuhen no kukan-teki henyo: Chiseki shiryo no bunseki wo chushin ni]. The Human Geography (Jimbun-Chiri) 55 (4) :24-45. (In Japanese)

Yamamoto, K., and S. Kobayashi (2012) Utilization of the Gaiho-zu [Gaiho-zu no katsuyo]. In historical GIS perspectives in Japan: Landscape reconstruction, environment and regional structure [Rekishi GIS no chihei: Keikan, kankyo, chiikikozo no hukugen ni mukete]. ed. Japan Council for Historical GIS Research, 57-67. Tokyo: Bensei Shuppan. (In Japanese)

Yamamura, A. (2009) The spatial structure of medieval cities [Chusei toshi no kukan kozo]. Tokyo: Yoshikawa Kobunkan. (In Japanese)

Yamane, H. and R. Nakanishi, eds. (2007) The making of regions in modern Japan: Historical-geographical approaches [Kindai Nihon no chiiki keisei: Rekishi-chirigaku kara no approach]. Otsu: Kaiseisya. (In Japanese)

Yamane, H. (2012) Introduction to the special issue: Rethinking modern historical geography in Japan [Nihon $n i$ okeru 'Kindai no rekishi-chiri' kenkyu no gaikan]. The Historical Geography (Rekishi Chirigaku) 54 (1): 1-4. (In Japanese)

Yamazaki, K., ed. (1985) A historical geography of early modern era [Kinsei rekishi-chirigaku]. Tokyo: Taimeido. (In Japanese)

Yamazumi, H. (1982) A historical geography of early modern villages [Kinsei sonraku no rekishi-chiri]. Kyoto: Yanagihara Shoten. (In Japanese)

Yamori, K. (1973) The picture map of Yonezawa castle town [Yonezawa joka-ezu ni tsuite]. Journal of History (The Shirin) 56 (2) :145-163. (In Japanese) 
Yamori, K. (1978) The antique maps of the castle town Fukui [Fukui joka-ezushi ni tsuite]. Historical geography research and urban research [Rekishi-chiri-kenkyu to Toshi-kenkyu Vol. 1]. ed. Professor Fujioka Kenjiro's retirement commemorative project society, 238-247. Tokyo: Taimeido. (In Japanese)

Yamori, K. (1979a) On the antique map of the castle-town Kanazawa (Kanazawa jokamachi-onezu) [Ontsugi goyo Kanazawa jyukyumai on-ezu to sono sakusei katei ni tsuite]. The Human Geography (Jimbun-Chiri) 31 (3): 77-88. (In Japanese)

Yamori, K. (1979b) The antique maps of the castle town Kanazawa [Kanazawa joka-ezushi ni tsuite]. Journal of History (The Shirin) 62 (3) :111-134. (In Japanese)

Yamori, K. (1982) A new interpretation Ochikochi Doin [Ochikochi Doin ni tsuite no shin-kaishaku]. ed. Tanaka, Y. Research on the regional history of the Japan sea, Vol. 4. [Nihonkai chiiki-shi kenkyu Vol. 4] 37-57. Tokyo: Bunken Shuppan. (In Japanese)

Yamori, K. (1984) Old maps and landscape [Kochizu to fukei]. Tokyo: Chikuma Shobo. (In Japanese)

Yamori, K., ed. (1987) The regional structure of castle towns [Jokamachi no chiiki-kozo]. Tokyo: Meicho Shuppan. (In Japanese)

Yamori, K. (1988) The morphology of castle towns [Jokamachi no katachi]. Tokyo: Chikuma Shobo. (In Japanese)

Yamori, K. (1989) The antique maps of the castle town Kumamoto [Kumamoto joka-ezu-shi ni tsuite]. Human geography's field of view [Jimbun-chirigaku no shiken]. ed. Professor Suizu Ichiro's retirement commemorative project society, 307-318. Tokyo: Taimeido. (In Japanese)

Yamori, K. (1992) A journey into old maps [Kochizu eno tabi]. Tokyo: The Asahi Shimbun Company. (In Japanese)

Yano, K., T. Nakaya, and G. Isoda, eds. (2007) Virtual Kyoto: Journey to the past, present, future Kyoto [Virtual Kyoto: Kako genzai mirai eno tabi]. Kyoto: Nakanishiya Shuppan. (In Japanese and English)

Yano, K., T. Nakaya, T. Kawasumi, and K. Tanaka, eds. (2011) Historical GIS in Kyoto: Bilingual version [Kyoto no rekishi GIS: Bilingual version]. Kyoto: Nakanishiya Shuppan. (In Japanese and English)

Yasuda, Y. (1980) An introduction of environmental archaeology [Kankyo kokogaku kotohajime]. Tokyo: NHK Shuppan. (In Japanese)

Yasuda, Y. (1990) Oscillation of climate and civilizations [Kiko to bunmei no seisui]. Tokyo: Asakura Shoten. (In Japanese)

Yoneyama, H., and N. Kawahara, eds. (2007) Transnational Japanese mobility in the modern era: The expenses of over seas Japanese and their descendents [Nikkei-jin no keiken to kokusai ido: Zaigai Nihon-jin imin no kingendai-shi]. Kyoto: Jimbun Shoin. (In Japanese)

Yonezawa, G. (2009) 3-D topographical analysis in Hanoi, Vietnam. Journal of Southeast Asian Studies 46 (4) :532540 .

Yoshida, T. (1983) Medieval rural settlements and their changes-Historical geographical reconsideration of shoson: dispersed dwelling settlements [Chusei sonraku no kozo to sono henyo katei: 'Shoson=sankyogata-sonraku' ron no rekishi-chirigaku-teki sai-kento]. Journal of History (The Shirin) 66 (3):80-146. (In Japanese)

Yoshida, T. (2008) The history of Honedera village told in picture maps and landscape [Ezu to keikan ga kataru Hondera-mura no rekishi]. Sendai: Honnomori. (In Japanese)

Yoshida, T. (2009) Development of medieval agriculture and the phenomenon of village clustering [Chusei nogyo no tenkai to shuson-ka gensho]. ed. Kondo S., Y. Kojita, R. Horace, and D. Taranchevski. Medieval period in Western Europe and Japan-era of multipolarity and divided power [Chusei Seio to Nihon: Tashu to bunken no jidai]. 111-124. Tokyo: Yoshikawa Kobunkan. (In Japanese)

Yoshikoshi, A., and H. Katahira, eds. (2012) Histrocal disasters in Kyoto [Kyoto no rekishi saigai]. Kyoto: Shibunkaku Shuppan. (In Japanese) 


\title{
1980年以降の日本における歴史地理学の動向
}

\author{
小野田一幸 (神戸市立博物館) \\ 宮本真二 (岡山理科大学) \\ 藤田裕嗣（神戸大学） \\ 米家泰作（京都大学） \\ 河原典史 (立命館大学) \\ 川口 洋 (帝塚山大学)
}

本稿では, 1980年以降の日本における歴史地理学, 地図史, および歴史 GIS に関する主要な研究成 果について展望する。この30年間にわが国では, H. C. プリンスによって定義された現実的世界, イメ ージの世界，および抽象的世界を対象とした豊かな研究成果が生み出されてきた。現実的世界を対象 とした研究では, 景観や地域構造の復原が引き続き基礎的課題となっている。とりわけ, 過去と現代 をつなぐ役割を担う近代期の研究意義が注目されるようになった。最新の研究動向として, 環境史と 学際的研究の進展があげられる。後者については, 地理学, 歴史学, 考古学の研究分野で史資料と研 究方法の共有化が進み, 歴史地理学の方法論が隣接分野に受け入れられて学際的研究に発展する動向 がみとめられる。イメージの世界については，過去に生きた人々の世界観に関する理解を深めるため に, 1980年代から古地図・絵図研究が本格化した。抽象的世界に関する研究は, 歴史 GIS を活用する ことにより，21世紀初頭から新たな段階を迎えた。歴史 GIS は，歴史地理学を含む人文・社会科学に おける個別研究の成果を統合する「しくみ」としても有用とみられる。

キーワード : 歴史地理学, 景観復原, 環境史, 地図史, 歴史 GIS, 学際的研究 